\title{
De arquitecto a empresario y rentista: perfil humano de Andrés García de Quiñones
}

\author{
María Nieves RuPÉREZ ALMAJANO \\ Universidad de Salamanca
}

\begin{abstract}
RESUMEN. En este artículo se pretende profundizar en algunas facetas de la vida de Andrés García de Quiñones. Soslayando su actividad como arquitecto, la atención se centra en su familia y en el análisis de sus disposiciones testamentarias, que confirman a través del inventario y reparto de sus bienes el enriquecimiento que logró al final de su vida. Como causa del mismo se analiza la faceta empresarial que desarrolló a partir de su marcha a Galicia y, en particular, el abasto de maderas para la construcción de navíos de la Real Armada que tuvo en Asturias. Su transformación, en último término, en propietario agrario viene a ser una manera de consolidar su ascenso social, que tiene también su reflejo en la casa que habitaba y en su atuendo. Finalmente se destacan algunos rasgos de su personalidad y el contenido de su biblioteca.

Palabras clave: Andrés García de Quiñones. Jerónimo García de Quiñones. Antonio Cándido García de Quiñones. Testamentos. Estilo de vida. Biblioteca. Astillero de El Ferrol. Salamanca. La Coruña. Asturias. Siglo XVIII.

ABSTRACT. The aim of this article is to delve deeper into certain facets of the life of Andrés García de Quiñones. Leaving to one side his activity as an architect, here we focus on his family and analyze the arrangements made in his will, which confirm that he was quite a wealthy man by the end of his life, given the inventory and the distribution of his worldly goods. To seek the source of this wealth we analyze his talent for business after he went to Galicia and, in particular, the supply of timber for building the ships of the Royal Armada that he had in Asturias. Ultimately, his transformation into a landowner was a way to consolidate his social rise, and this is also reflected in both the house he lived in and his attire. Finally, we point out certain traits of his personality and the contents of his library.

Key words: Andrés García de Quiñones. Jerónimo García de Quiñones. Antonio Cándido García de Quiñones.Wills. Lifestyle. Library. El Ferrol Shipyard. Salamanca. La Coruña. Asturias. 18th Century.
\end{abstract}

En la Edad Moderna es relativamente frecuente encontrar maestros de obras, escultores o pintores que compaginan su actividad artística con el desempeño de otros empleos como medio de aumentar sus ingresos y de mejorar su posición social. Fue también lo que hizo Andrés García de Quiñones especialmente cuando ya tenía una edad avanzada, pero en su caso la arquitectura pasó a un segundo plano frente a la primacía que tomaron otros negocios. Estos le proporcionaron al final de su vida la fortuna que no había logrado alcanzar con todo su prestigio como arquitecto. Nuestro propósito es abordar, a partir de una documentación en buena parte inédita, esta 
faceta empresarial de su trabajo y, en particular, las transformaciones que a raíz de la misma se produjeron en sus condiciones de vida en los años previos a su muerte. Por otra parte, pretendemos obtener una imagen más rica de su personalidad y aproximarnos a su mentalidad, en la que entran en juego no sólo intereses económicos o preocupaciones profesionales, sino también otras circunstancias menos materiales, como son los lazos familiares, sus relaciones sociales o sus creencias ${ }^{1}$. En definitiva, se trata de perfilar el aspecto humano, familiar y social del arquitecto.

\section{SU FAMILIA}

Como es sabido, Andrés García de Quiñones era hijo de don Antonio García Benítez y doña Josefa Quiñones Álvarez, natural de Villafranca de El Bierzo. De su padre sólo sabemos que era salmantino, bautizado en la parroquia de San Martín, pero desconocemos su profesión. Sin duda heredó de él la condición de hidalgo, que manifiesta orgulloso en el Catastro de Ensenada de 1753 , lo que justifica que ya desde 1729 su nombre aparezca precedido del apelativo "don", cuyo uso seguía siendo

${ }^{1}$ A. Rodríguez G. De Ceballos en su artículo, ya clásico, «Noticias sobre el arquitecto Andrés García de Quiñones», Archivo Español de Arte, 161 (1968), pp. 3543 , adelantó algunos datos al respecto, pero conviene corregir o puntualizar algunas de sus afirmaciones y completar otras, sobre todo a partir de la información que nos ofrecen el inventario y tasa de los bienes del arquitecto, que aquel creyó perdida, las ejecutorias de algunos de los pleitos que mantuvo y otras muchas escrituras y documentos de los que se ha tenido conocimiento.

2 Archivo Diocesano de Salamanca (ADS), 417/4, f. 119r. y v. Su madre era hija de Juan de Quiñones y María Álvarez y fue bautizada el 8 de mayo de 1686 en la parroquia de Santa Catalina. Archivo de la Real Chancillería de Valladolid (ARCHVa), Registro de Ejecutorias (RE), caja 3390/25, f. 3r. motivo de distinción a pesar de haberse generalizado notablemente ${ }^{3}$.

El 29 de diciembre de ese año contrajo matrimonio con doña Ana Josefa Otero Mendo en la parroquia salmantina de San Blas. ${ }^{4}$. No se puede decir que fueran pobres, pero los seis mil reales que cada uno aportó al matrimonio en bienes de distintas especies tampoco permite considerarlos como personas acomodadas. A juzgar por lo que sabemos fue un matrimonio muy bien avenido. Quiñones, según apunta su hijo Jerónimo, solía referirse siempre a su esposa como "mi mujer doña Ana" y en su vejez atribuía buena parte de los bienes que gozaban a su buen gobierno ${ }^{5}$. Juntos debieron de tomar la decisión de ingresar en la venerable Orden Tercera del Carmen Calzado y, el mismo día, presentaron la correspondiente solicitud, tomaron después el hábito $\mathrm{y}$, tras el preceptivo año de noviciado, hicieron a la vez la profesión el 17 de marzo de $1748^{6}$. Como prueba de la unión que seguía reinando entre ellos, el 29 de octubre de 1777 otorgaron un testamento conjunto y se nombraron uno al otro su albacea testamentario ${ }^{7}$.

3 Archivo Histórico Provincial de Salamanca (AHPSa), Catastro de Ensenada, libro 2056, f. 245. ADS, 415/26, f. 146. En el padrón de 1806 se da el distintivo "don" a un buen grupo de comerciantes "por sus destinos o empleos", pero como bien se advierte no debían tenerse por "hijosdalgo", salvo casos concretos. Archivo Municipal de Salamanca (AMS), caja 175 (3).

${ }^{4}$ Actuaron como testigos, además del padre del novio, don José Otero, hermano de la novia, y don Antonio Barba. Fueron velados el 16 de enero de 1730. ADS, 415/26, ff. 146-147.

${ }^{5}$ ARCHVa, RE, caja 3598-5, f. 47v.; AHPSa, Protocolo 3980, f. 775v.

6 Archivo de la Orden Tercera del Carmen (AOTC), Solicitudes de Ingreso de 1732-47 (2) y de 1748 a 1758; Libro de toma de hábitos de 1723-1764, f. 110r.; Libro de profesiones de 1724 a 1760, f. 159r.

${ }^{7}$ Lo mismo hicieron en el que otorgaron en 2 de 
Como fruto de su matrimonio tuvieron ocho hijos: cuatro varones y cuatro mujeres, aunque sólo la primera y la última superaron la infancia. El primogénito nació el 30 de septiembre de 1730 y fue bautizado diez días después en la parroquia de San Blas con los nombres de Jerónimo Francis$\mathrm{co}^{8}$. Siguió la profesión de su padre y trabajó bajo su dirección como aparejador y contratista en la Plaza Mayor. No se distinguió especialmente ni por sus dotes artísticas ni como tracista, pero tenía un buen dominio de la práctica constructiva, lo que unido al prestigio de su apellido le permitió dirigir obras destacadas en Salamanca y lograr, en último término, los títulos de maestro mayor del Cabildo en 1772, tras el éxito de la arriesgada empresa de reparación de la torre de la Catedral, y de maestro arquitecto del Ayuntamiento en 1773. Gracias a ello tuvo una posición dominante en el panorama arquitectónico salmantino del último tercio de siglo XVIII 9 .

Siendo todavía "oficial de cantería", el 3 de mayo de 1751 contrajo matrimonio en la parroquia de San Isidoro con Agustina Juliana de San Miguel y Olea, de su misma edad e hija de un maestro vidriero con el que Jerónimo compartió algunos trabajos ${ }^{10}$.

agosto de 1778. AHPSa, Protocolo 4145, ff. 560-561v. y Protocolo 5865, ff. 530-531v.

${ }^{8}$ ADS, 415/6, f. 246 . El padrino fue su tío José de Otero.

${ }^{9}$ Una breve biografía con sus intervenciones principales en Mª N. Rupérez AlmajANO, "García de Quiñones, Jerónimo", Diccionario Biográfico Español, T. XXI. Madrid, Real Academia de la Historia, 2011, pp. 229-231.

${ }^{10}$ ADS, 417/10 ff. 145v. 146 y 413/8, f. 44. AHPSa, Catastro de Ensenada, libro 2057, Relación de Jerónimo García. Salamanca 1753, según las Respuestas Generales del Catastro de Ensenada, Introducción de Miguel ARTOLA. Madrid, 1991, p. 217. Como aparejador recibía entonces siete reales diarios. En 1767 su suegro fue su fiador en la construcción de la capilla mayor, crucero y sacristía de la iglesia de Cordovilla, según planos de Juan de Sagarbinaga, y en la ermita de Aldehuela
Como era frecuente en las sociedades del Antiguo Régimen, varios de sus vástagos murieron prematuramente, pero sobrevivieron tres ${ }^{11}$ : María Francisca, Joaquín y Joaquina. La primera contrajo matrimonio con el abogado don Antonio Reyrruard y Merín, natural de Zafra, que llegó a ser catedrático de Vísperas de la Facultad de Leyes de la Universidad de Salamanca, siendo en último término Andrés García de Quiñones quien pagó los gastos ocasionados en 1779 con motivo de la recepción de los grados mayores de licenciado y de doctor, que ascendieron nada menos que a 22.000 reales $^{12}$; asombrosamente, don Antonio pasó de estar mantenido durante seis años en casa de su suegro a una desahogada posición económica, siendo uno de los principales compradores de la provincia en

de la Bóveda, con trazas de Francisco Pérez Estrada (AHPSa, Protocolo 4575, ff. 72-75v. y 92-97v).

${ }^{11}$ El primer hijo, Isidoro Vicente (30/3/1752), fue apadrinado por su abuelo Andrés García de Quiñones, pero no llegó a cumplir el año. A este le siguieron seis más, bautizados en las parroquias de San Isidoro y Santo Tomás Cantuariense: José Javier Casimiro (4/3/1754), M M ${ }^{a}$ Francisca Teresa (14/10/1755), M Ma Manuela de la Ascensión (15/5/1760), Joaquín Santos (1/11/1761), Juan Antonio Laureano (4/7/1765) y Joaquina Rosa (21/8/1768). ADS, 417/4, ff. 158r., 170, 181, 207 y libro 431/4, ff. 112v.-113 y 131.

${ }^{12}$ En el siglo XVIII se introdujeron algunas reformas en el ceremonial tradicional de estos grados para reducir gastos, pero aún así no estaban a la altura de cualquier bolsillo (Cf. J. L. POLO RODRÍGUEZ, «Ceremonias de graduación, siglos XVI-XVIII», Historia de la Universidad de Salamanca. II. Estructuras y flujos, Salamanca, 2004, pp. 897-908). Esta cantidad se la entregó inicialmente su suegro, pero en 24 de marzo de 1787 don Antonio Reyrruard entabló pleito contra la testamentaría de Andrés García de Quiñones para cobrar otro tanto, dado que al parecer éste se lo había ofrecido a su nieta con motivo de su boda, sin que lo hiciese efectivo cuando llegó el momento. Y ciertamente se le abonaron los dos mil ducados tras sentencia favorable de la real Chancillería de Valladolid de 23 enero 1789, de manera que recibió ese dinero dos veces. ARCHVa, RE, caja 3577-16; AHPSa, Protocolo 5774, f. 639 y Protocolo 3125 , ff. 112r.-114v. 
la desamortización de Godoy ${ }^{13}$. Joaquín siguió la carrera eclesiástica; en octubre de 1777 , a los 16 años, se matriculó por primera vez en la Universidad y en los tres años sucesivos superó los cursos de Súmulas y Lógica, Metafísica y Filosofía Moral necesarios para obtener el grado de bachiller en Artes, de manera que el curso 1780-1781 pudo matricularse en Leyes. Siendo sólo clérigo de primera tonsura, opositó a la capellanía fundada en Santo Tomás Cantuariense por Lucía Ruiz, que le fue finalmente adjudicada en junio de 1783 por sentencia de la Chancillería tras un reñido pleito ${ }^{14}$. Se ordenó presbítero en 1786, y para constituir la congrua sinodal su padre le cedió en vida su casa y, por su condición de primogénito, el vínculo de Villafranca del Bierzo con todas sus pertenencias ${ }^{15}$, del que hablaremos más adelante. Joaquina se casó con don Agustín Montojo, heredero de varios mayorazgos, y fue la única que dio cinco nietos ${ }^{16}$ a Jerónimo García de Quiñones. Éste murió el 13 de diciembre de 1808, a los pocos días de otorgar testamento, habiendo recibido los sacramentos y el viático. Llevaba más de dos años completamente impedido al cuidado de su hija $\mathrm{M}^{\mathrm{a}}$ Francisca, y aunque el Ayuntamiento acordó su jubilación en 1805, quiso al mismo tiempo mantenerle oficialmente el nom-

${ }^{13}$ AHPSa, Protocolo 3125, ff. 112r.-114v. R. HERR, La Hacienda Real y los cambios rurales en la España de finales del Antiguo Régimen, Madrid, I.E.F, 1991, pp. 807 y 821.

${ }^{14}$ La capellanía estaba dotada con una renta anual de 9.000 maravedíes y el producto del alquiler de una casa. ARCHVa, RE, caja 3495-39

${ }^{15}$ En esta ocasión se señala que Joaquín es "profesor de sagrados cánones en la Universidad"; más adelante llegó a ser fiscal general eclesiástico del tribunal metropolitano de Salamanca. AHPSa, Protocolo 5370, ff. 22r.-23v. y Protocolo 4296 (año 1794), ff. 115117.

${ }^{16}$ Cuando murió Joaquina eran muy pequeños, y dos de ellos -María y Agustín- los acogió en su casa su tía Maㅡ Francisca. AHPSa, Protocolo 3123, ff. 200-201. bramiento de maestro y la mayor parte de su sueldo, en atención a lo "puntual y exacto" de sus servicios, lo que dice mucho en su favor tanto desde el punto de vista profesional como humano ${ }^{17}$.

El segundo de los hijos de Andrés García de Quiñones, Antonio Cándido, vino al mundo 30 de abril de 1734 en la ciudad portuguesa de Viseu, a donde se había trasladado el arquitecto con su familia para ocuparse de la maestría del Convento de San Felipe Neri ${ }^{18}$. Al igual que su hermano Jerónimo se formó con su padre, tal como se había supuesto. De hecho, en el Catastro de Ensenada hay una puntualización a la declaración de Quiñones de 7 de mayo 1753 en la que se señala que su hijo Antonio Cándido, de 19 años, era "aprendiz de arquitecto"19. Debió de ser un joven un tanto impulsivo. A comienzos de 1760 se encontraba en la cárcel junto con José Pérez de Larrea porque con otros jóvenes que lograron escapar, habían participado en la noche del 2 de febrero en una reyerta en la plazuela del caño Mamarón, en la que resultó gravemente herido el carpintero Matías Berrocal, y él mismo no salió ileso. Su hermano Jerónimo tuvo que responder por ellos y otorgar la correspondiente escritura de fianza para poder sacarlos de la cárcel ${ }^{20}$. Posiblemente sentó un poco la cabeza al

17 AHPSa, Protocolo 3125 ff. 112-114v.; ADS, 414/16, f. 63. AMS, Actas consistoriales de 1805, ff. 214r., 292r. y Actas de 1809, f. 176r. Su mujer había muerto el 12 de diciembre de 1781 (ADS, 417/14, ff. 41v.-42).

${ }^{18}$ Archivo Distrital de Viseu, Registro parroquial Viseu Oriental, Cx. 32, no 7: Registro de Baptizados de la Sé, de 1725 a 1741, f. 79. Sobre este trabajo, Ma N. Rupérez AlMAJANO, «Los inicios profesionales de Andrés García: su actividad en Portugal y Ciudad Rodrigo», en Goya (en prensa).

${ }^{19}$ Además tenía otro aprendiz de 18 años, José de la Fuente. AHPSa, Catastro de Ensenada, libro 2056, f. 245.

${ }^{20}$ AHPSa, Protocolo 3605, ff. 676, 618 y 626. 
contraer matrimonio con $\mathrm{M}^{\mathrm{a}}$ Teresa Hernández el 3 de mayo de 1761, en el camarín de Nuestra Señora de los Remedios de la parroquia de San Julián y Santa Basilisa. Tuvo al menos cuatro hijas: María, Josefa, Ana María y Joaquina ${ }^{21}$.

Mientras Jerónimo se quedó en Salamanca, en torno a 1765 Antonio Cándido acompañó a Galicia a su padre, que había conseguido el asiento para construir el Archivo Brigantino. Permaneció avecindado en tierras gallegas hasta su muerte, que debió de producirse en Betanzos a mediados de $1788^{22}$. Allí alcanzó reconocimiento como arquitecto y, según Sánchez García, disfrutó como tal de una posición privilegiada. De hecho el Ayuntamiento de la Coruña cuando tenía entre manos proyectos de mayor envergadura recurría frecuentemente a él en lugar de servirse del fontanero y maestro de obras de la Ciudad, Antonio Fontela. El propio Ventura Rodríguez consideraba en 1778 que era un maestro "inteligente y práctico", pero hubo quien fue más lejos y le calificó como "el arquitecto de mayor fama del Reino" ${ }^{23}$, con una

${ }^{21}$ ADS, 420/12, f. 247 y 437/6, f. 81r. ARCHVa, RE, caja 3598-05. Su hija "María Bernarda Benita" nació todavía en Salamanca el 21 de marzo de 1764. Se casó con don Antonio González Viejo, al que en alguna ocasión dio poder Andrés García de Quiñones para representarle en Galicia, y Joaquina con don Rodrigo González Viejo, instalándose en León.

${ }^{22}$ El 4 de julio de 1788 se nombra curador para dos de sus hijas que seguían solteras. Unos años antes, en 1784, con ocasión del pleito Agar - Elexalde ya se alude a la grave enfermedad que le mantenía en cama, lo que no le impedía seguir haciendo planos para la casa de don José Ramos, que estaba dirigiendo. ARCHVa, RE, caja 3598-5, f. 42. J. A. SÁNCHEZ GARCíA, «Comerciantes y arquitectura en La Coruña dieciochesca: el proceso constructivo de las "Casas de Paredes», Semata: Ciencias sociais e humanidades, 12 (2000), p. 233.

${ }^{23}$ Ibidem, p. 195 y 233. J. A. SÁNCHEZ GARCía, «Maestros de obras y aparejadores en la época contemporánea», El aparejador y su profesión en Galicia: de los maestros de obras a los arquitectos técnicos, La Coruña, exageración notable aun tratándose sólo de Galicia. Sin que cuestionemos sus aptitudes profesionales, al igual que sucedió con su hermano Jerónimo, el nombre de su padre y sus relaciones con algunos de los más importantes hombres de negocios de la Coruña, como Jerónimo Hijosa, favorecieron sin duda su actividad, que resulta todavía poco conocida a pesar contar con algunos datos ${ }^{24}$. Si hablando de su hijo Jerónimo, Andrés García de Quiñones apuntaba que era "arquitecto mayor...de esta ciudad", al referirse a Antonio Cándido, no menos orgulloso, destacaba su papel de "arquitecto y director general de las Calzadas Reales del Reino de Galicia"25.

El resto de los hijos fueron todos salmantinos. En la parroquia de Sancti Spíritu, donde se avecindó el matrimonio al regresar de Portugal, nacieron $\mathrm{M}^{\mathrm{a}}$ Eugenia, el 15 de noviembre de 1736, y Andrés An-

2001, pp. 144 y 184 .

${ }^{24}$ Entre sus obras documentadas habría que señalar la construcción hacia 1770 del santuario de la Angustia (Betanzos) y del Ayuntamiento de Betanzos en 1778 , con arreglo a planos suyos corregidos por Ventura Rodríguez, que da un nuevo diseño para la fachada. El mismo año se presentó a la obra de reconstrucción del cuartel de Santiago para convertirlo en Hospicio. En los años 80 dirigió la construcción del camino que iba de la Coruña a Betanzos y proyectó la Colegiata de Ribadeo (1785), que no se llegó a edificar. En la Coruña consta su intervención en reconocimientos, tasaciones y obras de diversa importancia, como en el teatro viejo de Nicolás Setaro, la Sala de la Discordia y de las bóvedas bajo el palacio de la Audiencia para convertirlas en archivo, los voladizos del caserío coruñés, la casa de don José Ramos para instalar el Consulado marítimo o la Real Aduana. J. GARCÍA-ALCAÑIZ YUSTE, Arquitectura del neoclásico en Galicia. La Coruña, 1989, pp. 32 y 212-213, J. A. SÁNCHEZ GARCÍA, "Comerciantes...», art. cit. 195-196 y 233 y "Maestros de obras...", art. cit. p. 223. A. VIGO TRASANCOS, A Coruña y el siglo de las Luces. La construcción de una Ciudad de Comercio (1700-1808). Santiago de Compostela, 2007, pp. 143144, 161-163, 215, 221-225 y 292.

${ }^{25}$ AHPSa, Protocolo 3980, f. 776. Sobre la construcción e importancia de este camino real, M. GARCÍA FUENTES, El camino de acceso a Galicia en el siglo XVIII. La Coruña, 1987. 
tonio el 11 de enero de $1741^{26}$, posiblemente los que más preocuparon a sus padres. $\mathrm{M}^{\mathrm{a}}$ Eugenia se casó el 3 de diciembre de 1764 con el médico don José Pablo Núñez, pero hasta que éste encontró empleo en Hervás, Quiñones los mantuvo en su casa durante un año y les costeó después el viaje, además de ponerles "decentes a ambos" y darles el ajuar más necesario. Al quedar viuda en 1768 con dos hijos de corta edad -Ramón y Vicente-, sus padres decidieron hacerse cargo de todos ellos y, como residían entonces en la Coruña, Jerónimo se ocupó de trasladar allí a su hermana desde Hervás, con todas sus pertenencias. Andrés García de Quiñones pagó desde entonces su manutención y también los estudios de esos nietos en la Universidad. A cambio $M^{a}$ Eugenia se ocupó de cuidar y atender con gran desvelo y cariño a sus padres en los últimos años de su vida ${ }^{27}$.

También en su compañía y bajo su protección estuvo siempre su hijo Andrés. Al parecer tenía alguna deficiencia, probablemente un retraso mental, porque según algunos testigos su madre, estando muy grave y sin duda preocupada por su futuro, se refirió a él como "el pobre burro de Andrés" ${ }^{28}$. Esto explicaría que permaneciese soltero y que careciese de una profesión definida. Quizá para estimularle y también como medio de favorecerle, durante los

\footnotetext{
${ }^{26}$ Maria Eugenia fue bautizada el 25 de noviembre de 1736 y Andrés Antonio el 23 de enero de 1741. En ambos casos el padrino fue don Antonio Valdés Flórez, estanquero al por menor. ADS, 437/5, ff. 40v. y 71 . AHPSa, Catastro de Ensenada, libro 2056, ff. 130-133.

${ }^{27}$ ADS, 417/10, f. 184. Fueron testigos de la boda el padre de la novia y su hermano Francisco. AHPSa, Protocolo 5865, ff. 530-535 y Protocolo 3980, f. 776v. Además de sus vestidos, algunos ajuares de casa y ropa blanca llevó a casa de sus padres varios libros de medicina y vestidos de su marido que se entregaron a su hermano Francisco; todo ello, según cálculo de Quiñones, valdría unos 1.500 reales.
}

${ }^{28}$ ARCHVa, RE, caja 3598-05, f. 35r. años en que vivieron en Asturias ocupándose del asiento de maderas para la Armada -al que aludiremos más adelante- Andrés García de Quiñones le debió de confiar algún encargo y le hizo acompañar al contramaestre a Cangas, Infiesto, Soto de los Infantes, al monte de Muniellos, etc., por lo que del 20 de enero de 1772 al 31 de diciembre de 1775 le adjudicó un sueldo, primero de trece reales diarios y luego de quince, a todas luces demasiado elevado para quien ni antes ni después fue capaz de vivir con autonomía propia. No obstante, según la cuenta detallada que se encontró entre los papeles de su padre, era más bien un sueldo nominal, del que éste iba descontando el gasto de su manutención, lo que le entregaba para sus gastos, para comprarse vestidos, para ir a las ferias, a Oviedo, etc., sin hacerle efectivo nunca el total ${ }^{29}$. Muerto Quiñones, siguió viviendo con su hermana Ma Eugenia, mientras su cuñado don José López Sopuerta se ocupaba de proporcionarles lo que necesitaban. Falleció el 16 de febrero de 1789 y fue enterrado en San Isidoro, en la sepultura de sus padres ${ }^{30}$.

El cuarto hijo varón, Francisco Antonio de Paula nació el 25 de junio de 1743 en

\footnotetext{
${ }^{29}$ Teniendo esto en cuenta se entiende que Andrés y su mujer declaren en el testamento de 2 de agosto de 1778 que los dos baúles que tenía su hijo Andrés con todos sus vestidos, ropas y alhajas, eran de su propiedad, "por haberlos comprado con los sueldos que debengó y ganó en el tiempo que estuvo con nosotros en Asturias", y que además le entregasen "6.000 reales" que eran suyos "por haberlos ahorrado de los expresados sueldos", en el caso de que no se los hubiesen dado antes de morir. Esta cantidad es prácticamente la que quedaba de los sueldos teóricos una vez descontados los gastos anotados por su padre (AHPSa, Protocolo 5865, f. 533, ARCHVa, RE, caja 3598-05, ff. 33v.-34r.). No obstante, Andrés García de Quiñones en 1784 indica sólo que no se le rebaje de las legítimas la ropa de su uso (AHPSa, Protocolo3980, f. 777r.)

${ }^{30}$ Otorgó testamento en 28 de agosto de 1788 y codicilo en 17 de enero de 1789. ADS, 420/15, f. 123r.; AHPSa, Protocolo4226, f. 336 y Protocolo 4227, f. 365.
} 
la parroquia de San Blas ${ }^{31}$ y cursó en la Universidad los estudios de medicina. Siendo ya bachiller, en octubre de 1769 con el fin de poder pasar el examen del Real Protomedicato y obtener la autorización que le permitiese ejercer como médico, ofreció como era habitual la pertinente información de limpieza de sangre, en la que se atestigua que tanto sus padres como sus abuelos "eran cristianos viejos y libres de toda mala raza de judíos, moros, erexes, combersos y villanos y ninguno de ellos ha sido penitenciado por el santo tribunal de la Ynquisición, ni menos ha tenido borrón ni nota pública que desluzca su nacimiento en los sobre dichos asuntos ni en el haver exercido oficios viles"32. Contrajo matrimonio con doña María Osorio el 18 de noviembre de 1765 en la iglesia de San Blas, si bien sus padres siguieron contribuyendo algún tiempo a su manutención, pagaron el coste de revalidarse y le compraron vestidos, libros y otros efectos, superando con creces lo gastado con otros hijos que se habían casado. Seguía avecindado en Salamanca en noviembre de 1770, cuando murió su primer hijo, pero unos años después ocupaba la plaza de médico titular en el Acebo, en Extremadura, donde se afincó $^{33}$.

\footnotetext{
${ }^{31}$ Fue bautizado el 2 de julio de 1743, siendo su padrino don José Antonio de León y Luna, contador principal del ejército y provincia. ADS, 415/7, p. 72v.

32 AHPSa, Protocolo 3706, ff. 409-417. Uno de los testigos, Blas de Tejeda, de unos sesenta años, declara que trató mucho a Andrés García de Quiñones y que también conoció mucho a los abuelos paternos. Sobre el requisito de limpieza de sangre, M. S. CAMPOS DíEZ, El Real Tribunal del protomeditaco castellano (siglos XIVXIX). Cuenca, 1999, pp. 105-109.

33 ADS, 415/27, f. 194. En el testamento de 1777 calculaban el mayor gasto con este hijo en 15.000 reales, pero se había incrementado casi al doble -29.600 reales- cuando murió su padre. AHPSa, Protocolo 4145, f. 561 y Prot 5774, ff. 635 y ss. Su hijo Joaquín había nacido en 1768 y murió 7 de noviembre de 1770. ADS, 415/7, f. 326r. y 415/32, f. 110.
}

En la parroquia de San Isidoro y San Pelayo, donde Andrés García de Quiñones y su mujer se asentaron definitivamente, nacieron las tres últimas hijas: Rosa en 1746, Isabel en $1748 \mathrm{y}$, finalmente, el 14 de diciembre de 1749 Josefa Anastasia, que fue la única que superó la infancia ${ }^{34}$. A diferencia de sus hermanos, Josefa se casó con más edad de lo que era habitual en la época, por lo que no resulta extraño que lo hiciera con un viudo: el escribano don José López Soporta. Curiosamente el mismo día de su boda, el 29 de junio de 1778 día de San Pedro, se celebró la de su sobrina $\mathrm{M}^{\mathrm{a}}$ Francisca, hija mayor de Jerónimo, con don Antonio Reyrruard ${ }^{35}$, lo que es un buen reflejo de la armonía que reinaba entonces en la familia. Es también un claro testimonio de la posición económica mucho más desahogada que por entonces gozaba Quiñones, lo que le permitió gastar en la celebración "cien doblones" y ofrecer a esta "mui querida y amada hija", por vía de dote, la elevada cantidad de 50.000 reales: 33.000 en dinero a cuenta de sus legítimas y los 17.000 restantes en diferentes alhajas de plata, oro, diamantes, vestidos y demás ropa de su uso, en concepto de mejora por ser "la mas pequeña de todos sus hijos". El novio por su parte prometió a su futura esposa 5.500 reales en atención "a la calidad, pureza y relevantes prendas" que

\footnotetext{
34 Rosa Isabel Dorotea nació el 6 de febrero de 1746 y fue bautizada el 11. El padrino fue su tío don Santiago García de Quiñones. Isabel María Polonia nació el 9 de febrero de 1748 y fue bautizada el 25 de ese mes, siendo su padrino el procurador del número don Francisco González Blanco. Josefa Anastasia fue bautizada el 23 de diciembre de 1749, actuando como padrino Miguel Martín. Cuando se realiza el Catastro en 1753 ya no vivían ni Rosa ni Isabel. ADS, 417/4, ff. 119, 132, 143. AHPSa, Catastro de Ensenada, libro 2056, f. 245.

35 José López Sopuerta debió de nacer en 1742, pues en 1788 tenía 46 años. Las bodas las ofició su hermano don Juan López Sopuerta. ADS, 417/10 Libro de matrimonios de San Isidoro de 1701 a 1814, ff. 240v.-241v.
} 
concurrían en ella, aunque aún no cabían en la décima de sus bienes, lo que refleja bien los recursos de uno y otro. Además debieron entregarles una "palancana, jarra y jabonera de plata con ricos paños de afeitar" $^{\prime \prime}, \mathrm{y}$ otras cosas que les dio su madre ${ }^{36}$.

Aprovechando la dote de su esposa, José López Sopuerta compró un oficio de procurador para su hermano Diego, del que Josefa se considerará años después legítima propietaria y con derecho al usufructo, como hace constar en su testamento otorgado el 10 de enero de 1807, apenas un mes antes de su muerte ${ }^{37}$. Tuvieron dos hijas: María de los Remedios, que se casó con un profesor de la Universidad, el doctor Manuel Domínguez que murió pronto, y Juana. A falta de descendencia masculina, después de morir su marido Josefa vendió el oficio de escribano a su sobrino don Vicente Núñez, hijo de $M^{a}$ Eugenia. Tanto ésta como su hermana habían recibido una mínima instrucción, de la que posiblemente se había ocupado su propio padre García de Quiñones. Prueba de ello es que ambas sabían firmar, lo mismo que su madre Ana Otero, y también leer, pues tenían algún libro de devoción.

\section{LAS DISPOSICIONES TESTAMENTA- RIAS: INTERESES Y CONFLICTOS}

A raíz del matrimonio de la hija menor la estrecha unidad y armonía que había existido hasta entonces en la familia de Quiñones empezó a resquebrajarse. La influencia $\mathrm{y}$, muy posiblemente, también la ambición del nuevo yerno debió de jugar un papel decisivo en la situación que se

${ }^{36} \mathrm{El}$ hecho de que la mayor parte de la dote fuese en dinero es también significativo. AHPSa, Protocolo 5865, f. 264. AHPSa, Protocolo 3980, f. 777r.

${ }^{37}$ Murió el 27 de febrero de 1807 y fue enterrada en San Julián. AHPSa, Protocolo 3849, ff. 300-301v. ADS, 420/15, f. 182r. creó. De inmediato se tradujo en el intento de alejar a Jerónimo de sus padres, cuando -según declararon algunos testigos- éstos solían comentar que habían decidido volver a Salamanca después de pasar más de diez años en Galicia y Asturias, precisamente "para bibir y morar en compañía del hijo mayor don Gerónimo Quiñones como a quien más amaban y a quien no querían ocultar los restantes hermanos que tenían consigo -esto es, Ma Eugenia, Andrés y Josefa- los bienes de fortuna que Dios les había dado". Ciertamente se comprueba que Andrés García de Quiñones se apoyó en ese hijo para resolver negocios de lo más dispares, unos de cierta entidad y otros de carácter puramente doméstico. Estando en la Coruña, le encomendó, por ejemplo, que se ocupase de "descubrir y sacar en limpio los papeles de hidalguía" que le correspondía por su nacimiento; asimismo fue Jerónimo, en su nombre y como primogénito varón, quien realizó los trámites para recobrar y tomar posesión en Villafranca del Bierzo del vínculo que pertenecía a Andrés García de Quiñones por herencia de su madre. También hizo la primera solicitud para la fundación de misas que deseaban sus padres o gestionó la compra de una salvilla y una bandeja de plata a un monje jerónimo con el que tenía amistad ${ }^{38}$, por no citar los servicios prestados al resto de los hermanos, como los aludidos al hablar de Antonio o $\mathrm{M}^{\mathrm{a}}$ Eugenia. Tal era la confianza en su primogénito que sus padres le nombraron único albacea en su primer testamento.

Es precisamente a través de los testamentos suscritos por Andrés García de Quiñones y su mujer Ana Josefa de Otero como mejor se puede entrever la evolución en las relaciones familiares y algunas de las preocupaciones que marcaron el final de

38 ARCHVa, RE, caja 3598-05, f. 35v., 46r.; AHPSa, Protocolo 3980, ff. 774-779v. 
sus vidas, así como la prosperidad en que vivían.

El matrimonio otorgó de manera conjunta su primer testamento al poco tiempo de su regreso a Salamanca, el 29 de octubre de 1777 ante el escribano Simón Suárez ${ }^{39}$, estando presentes todos los hijos que vivían en la ciudad. Antes quisieron hablar con el padre Saldaña, un capuchino que tenía fama de virtuoso. Como es habitual, las primeras disposiciones se relacionan con el entierro y los sufragios por sus almas. Así, después de declarar su fe en el misterio de la Trinidad y en todo lo que cree la Iglesia católica, apostólica y romana, y después de tomar como intercesora a María Santísima Reina de los Ángeles, al Ángel de la Guarda y a todos los santos, en particular a los de sus nombres, manifiestan su deseo de ser amortajados con el hábito de Nuestra Señora del Carmen, como hermanos profesos de la Venerable Orden Tercera, de ser enterrados en la sepultura de su propiedad que tenían en la iglesia de San Isidoro y de que asistiesen al entierro las cofradías de Nuestro Señor de esta misma iglesia y de San Blas, en las que habían servido como mayordomos, la de Ánimas de la parroquia de San Julián, la de Nuestra Señora de San Millán, la de Nuestra Señora de la Caridad de San Bartolomé y la de San Juan de los canteros situada en el convento de San Francisco, y que todas hiciesen los oficios acostumbrados con sus hermanos. También piden que asistan al entierro y oficios de noveno y cabo de año, a cantar la vigilia y misas, los religiosos del convento de San Francisco "que llaman la música". Mandan finalmente decir por sus almas los tres oficios parroquiales acostumbrados y veinte misas rezadas por cada uno de cuerpo presente, en los días del entierro y noveno.

${ }^{39}$ AHPSa, Protocolo 4145, ff. 560-561v. ARCHVa, RE, caja 3598-5, f. 34v.
La parte relativa a los asuntos materiales es en proporción bastante breve. Se limitan a señalar que los bienes que poseen son todos gananciales, obtenidos durante su matrimonio; recuerdan los 360.000 reales que todavía les adeudaba la corona del asiento de las maderas y lo entregado de más a Francisco a cuenta de sus legítimas, dejando a los seis hijos herederos por partes iguales. Años después, en 1787, se destacaba que esta igualdad entre los hijos había sido el deseo de sus padres cuando gozaban de "entera y perfecta libertad". Es más, un testigo resaltó la generosidad manifestada entonces por Jerónimo que, "como un segundo padre de sus hermanos", consintió que no se les cargase en legítimas tanto como habían percibido y renunció a la manda que intentaban darle "como a hijo mayor que tanto les había ayudado a unos y a otros", porque según señaló "le importaban menos los intereses que la paz de todos ellos" ${ }^{\prime 4}$. Fueron testigos del testamento el cirujano don José González y los notarios del tribunal eclesiástico don Diego de la Torre y don Melchor Pérez Torres. Con este último debía unirles una especial y vieja amistad, pues había compartido con García de Quiñones la mayordomía de la cofradía del Santísimo de San Isidro en 1755 y estuvo presente como testigo en la boda de sus hijas y en otros acontecimientos familiares ${ }^{41}$.

En previsión de una muerte que veía ya cercana, Andrés García, que se encontraba por entonces en cama con algunos "achaques habituales, quiso con grandes ansias" tener sepultura propia para él, su

${ }^{40}$ Ibidem.

${ }^{41}$ ADS, 417/26, 1732-1793, ff. 58v., 62 y 66 y 417/10, ff. 184r.y 240v. Fue también testigo en la compra de la hacienda de don Nicolás Romero y en nombre de Quiñones entregó un dinero a censo a los Carmelitas Calzados (AHPSa, Protocolo 5768, ff. 67-82 y Protocolo 5215, ff. 531 y ss). 
esposa y sus herederos y, el día anterior a la firma del testamento, formalizaron también la compra de la sepultura número 49 en la capilla mayor de la iglesia de san Isidoro y San Pelayo, "en la tercera fila al lado del evangelio". Pagaron por ella 400 reales en monedas de oro $^{42}$. Al mismo tiempo, Jerónimo expuso a la cofradía del Santísimo de esa misma iglesia el deseo de sus padres de instituir "para exaltar el culto de Dios Nuestro Señor y de su Santísima Madre" y en beneficio de sus almas y las de sus padres, dos misas perpetuas cantadas, con diacono, subdiácono y responso al final, y con asistencia de los mayordomos y miembros de esa cofradía, a la que también ellos pertenecían. Las misas se celebrarían el día de la fiesta o en la octava de San Andrés apóstol y de Santa Ana, sus correspondientes patronos. Durante su celebración se pondría "tumba, cruz, cuatro achas, dos velas sobre el altar, otras dos a Nuestra Señora y otras dos en la tumba" y se daría cera a cada uno de cofrades que asistiesen desde "el primer evangelio hasta finalizar el responso, según estilo de la cofradía de la Santa Cruz del campo de San Francisco de esta ciudad". Para cumplir este deseo ofrecieron 132 reales para las dos primeras misas y otros 4.400, que aplicados a censo al $3 \%$ proporcionarían los ingresos necesarios para poder celebrarlas cada año con las condiciones establecidas. Andrés García de Quiñones reiteró de nuevo la solicitud a la cofradía a través de un memorial y después de varias juntas y de obtener la licencia del provisor, el 26 de noviembre de 1777 él y su esposa otorgaban la escritura de fundación que hacía realidad su deseo ${ }^{43}$.

\footnotetext{
42 AHPSa, Protocolo 3710, ff. 123-125v.

${ }^{43}$ AHPSa, Protocolo 3710, ff. 298-302 y 303-310v.
} Andrés García de Quiñones detalló en su memorial, como quien tenía buen conocimiento, el destino de los 66 reales de cada misa, que incluía la limosna a los beneficiados, los vestuarios, la cruz que debía ponerse
Esta fundación de misas es muestra de la sincera preocupación del arquitecto y su esposa por la salvación de sus almas, y constituye una prueba más de su profunda religiosidad y de su piedad personal, que ya se había puesto de manifiesto con su ingreso en la Venerable Orden Tercera del Carmen, al margen de su pertenencia a diversas cofradías, apuntadas más arriba, en donde las motivaciones sociales podían estar más presentes.

Apenas un mes después del matrimonio de Josefa, el 2 de agosto de 1778, Quiñones y su mujer volvieron a otorgar testamento, esta vez ante el escribano Agustín Manuel Anieto cuñado de su yerno José López Sopuerta ${ }^{44}$. Las disposiciones relativas al entierro y misas son las mismas, pero hay un cambio significativo con respecto al anterior en las cláusulas económicas. Aunque nominalmente siguen declarando a todos sus hijos herederos de sus bienes a partes iguales, incluyen unas cláusulas que de hecho dan un trato de favor a los que vivían con ellos y a la menor. Así, si por un lado vuelven a recordar los 15.000 reales entregados a Francisco para que se descontasen de sus legítimas, por otro reiteran los 17.000 de mejora incluidos en las capitulaciones matrimoniales de Joaquina y especifican que no se tuviese en cuenta lo gastado en la manutención de $\mathrm{M}^{\mathrm{a}}$ Eugenia y de sus hijos, ni lo comprado para su uso y decencia, ni las camas en que dormían. Además declaran como pertenecientes a Andrés dos

\footnotetext{
y toque de campanas, el coste de la cera que debía arder durante la vigilia, misa y responso y la que se daría en mano a los cofrades que asistiesen, lo que se repartiría a esos mismos cofrades, lo entregado al mayordomo por los ornamentos y al sacristán por el vino y la oblata.

44 AHPSa, Protocolo 5865, ff. 530-531v. Anieto y Soporta habían estado casados con dos hermanas y este hecho conllevaba sospecha legal y nulidad del documento por razón de parentesco según las leyes de Carlos V y Felipe II.
} 
baúles con su contenido y otros 6.000 reales que todavía no le habían entregado de sus sueldos, según lo que hemos apuntado más arriba. Como albacea aparece también ahora el yerno. Jerónimo García de Quiñones había pensado que la animadversión que advertía en Sopuerta se dirigía únicamente a impedir que tuviese efecto el regalo que sus padres habían ofrecido a la nieta mayor, $\mathrm{M}^{\mathrm{a}}$ Francisca, con motivo de su boda, de darle cuando llegase el momento el importe de los grados de su marido, pero pronto pudo comprobar que fue mucho más lejos.

El 21 de febrero de 1780 Quiñones y Ana Otero otorgaron un codicilo en el que añadían algunas particularidades al testamento anterior. Hacían constar que habían dado a su hijo Jerónimo en dinero a cuenta de sus legítimas 21.422 reales, aunque no había hecho resguardo más que de 18.000, y otros 1.822 a Francisco además de los 15.000 ya señalados. Pero fundamentalmente instituían un legado de 66.000 reales en favor de $M^{a}$ Eugenia, Andrés y Joaquina, a razón de 22.000 para cada uno, sin más excusa para esta mejora que "justas y razonables causas que les mueben y a consecuencia de los buenos servicios que les han hecho" 45 .

Los otros hijos sólo tuvieron noticia de la existencia del testamento de 1778 y del codicilo posterior cuando murió su madre, el 22 de febrero de $1780^{46}$, justo al día siguiente de haberlo otorgado, y no pudieron menos de sentirse disgustados por estas discriminaciones, especialmente porque no creían que la iniciativa hubiese partido de sus padres ni fuese acorde con su modo de proceder hasta entonces. Según denunciarían años después, en especial la última cláusula era fruto de las maniobras llevadas a cabo por los hijos que tenían "a su vista y compañía", quienes no contentos

\footnotetext{
45 AHPSa, Protocolo 5868, f. 238.

${ }^{46}$ ADS, 423/26, f. 241.
}

con que les dejasen los baúles con lo que tuviesen dentro -"por cuia causa aparecían tan rellenos como desocupados los demás" -, ni con que a Andrés se le diesen 6.000 reales por sus salarios - "quando ni los hubo ni los permite la ley de Partidas que dispone que no pueda el hijo pedir salario al padre por el tiempo que había servido" -, intentaron obtener mayores beneficios abusando de la "edad y achaques de los padres que les impedía salir de casa" y les obligaron, con "violencia, sugestiones y suplicas", a que firmasen lo que se les antojaba. Así habían conseguido -según los hijos perjudicados- el codicilo, con la colaboración de un notario favorable y sirviéndose como testigos de los criados de la casa Agustín Pérez y José Bernardo Soria, contra la prohibición de la ley de Partidas. La declaración de uno de estos criados ilustra de manera muy gráfica la presión ejercida por $M^{a}$ Eugenia y su cuñado Soporta sobre Ana Otero, cuando estaba ya moribunda, para que firmase y cómo se resistía a hacerlo sin conocer antes el pensamiento de su mari$\mathrm{do}^{47}$.

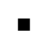

47 Señala Agustín Pérez en su declaración que "una de las noches en que estaba ya bastante mala doña Ana me dijo don José Sopuerta vete a acostar y buelbe dos oras antes de amanecer sin falta, respondiole que para eso era mejor quedarme allí a dormir pero no lo consintió; fui en efecto como entre tres y cuatro de la mañana y allé levantado dicho Soporta con su cuñada doña María y el criado de la casa José Bernardo Soria, como una ora después entró el escribano con su amanuense Manuel Zamorano y sin armar ruido para que no despertase la familia, se entraron al cuarto de la enferma y empezaron los citados Soporta y cuñada a suplicar las mejoras ponderando varias cosas, pero doña Ana se resistía diciendo que por qué lo havía de hacer con ellos y no con los demás, para lo qual recordó al don Andres con estas palabras y el pobre burro de Andrés, digeron entonces que también podía mejorarlo, pero replicó y mi marido que dice de esto? Al mismo tiempo entraba y salía en su alcoba que estaba pared por medio dicho Sopuerta y después de varios recados que daban, que ni don Andrés quería condescender antes que su mujer ni tampoco se atrevía esta a no ser en favor del más 
Andrés García de Quiñones estaba por entonces en cama con grandes dolores y la enfermedad limitó cada vez más su movilidad. A causa de una "formidable gota" prácticamente no podía levantarse de un sillón ni salir de casa y tenía siempre alrededor a María, Andrés y Josefa, y a toda la parentela del marido de ésta, que no dejaban acercarse al resto de sus hermanos, pues "entrando alguno de ellos le desairaban, ponían mala cara y no lo dejaban jamás de la bista para que nada pudiese hablarles el tullido don Andrés, de este modo se havían apoderado de la casa y en esta forma tenían oprimido al benerable anciano"$^{\prime 48}$.

En esta situación en que era prácticamente imposible hablar a solas con él, se entiende el medio urdido por Jerónimo para sustraer a su padre de esta presión. Después de haber intentado muchas veces, sin conseguirlo, que fuese a comer a su casa, por fin, la mañana del 27 de abril de 1784 logró llevarlo a pasear en una berlina hasta la plazuela de San Vicente, un lugar muy concurrido por todo tipo de gentes, desde los que acudían a la iglesia del monasterio benedictino hasta los aguadores y lavanderas que subían del río por la puerta de San Vicente. Allí le esperaban el escribano José Manuel López, un notario eclesiástico y varios profesores de la Universidad, seguramente amigos de don Antonio Reyrruard, yerno de Jerónimo, que fueron testigos de un nuevo testamento otorgado por Andrés García de Quiñones", "libre de las sugestiones y miedo que padecía en

-

digno por sus méritos y virtudes". ARCHVa, RE, caja 3598-5, f. 35.

${ }^{48}$ Ibídem.

${ }^{49}$ Según denunciaron los contrarios, este escribano era íntimo amigo de Jerónimo y de su yerno don Antonio Reyrruard. AHPSa, Protocolo 3980, ff. 774-779v. ARCHVa, RE, caja 3598-05, f. 35. casa" y "lejos de los hijos que le obligaban a que se les dejase todo su caudal".

Según testimonio de Jerónimo, su padre había dado al escribano dos o tres meses antes un borrador escrito a solas de su puño y letra para que extendiese el testamento en limpio. Esto podría explicar el marcado carácter personal que transmiten algunas disposiciones, con alusiones a pormenores familiares que no son frecuentes en este tipo de documentos ${ }^{50}$, pero justificables aquí por su deseo no sólo de revocar lo que en los testamentos anteriores tenía visos de trato de favor -que su mujer y él se habían visto obligados a firmar-, sino también de establecer un reparto más equitativo de sus bienes, al no existir razón alguna para hacer diferencias entre los hermanos, cuando "ni de mi hijo don Jerónimo, ni de don Candido o don Francisco tengo queja alguna, pues todos a competencia me aman y veneran y lo mismo hicieron con su difunta madre"...y "...para que no me tome su divina Magestad en cuenta el haber hecho alguna o algunas mejoras dando ocasión a que haya después celos sobre mi amor, se juzguen algunos agraviados y se rompan con pleitos y discordias los vínculos de hermandad...".

Teniendo ahora ocasión de hablar libremente -"con arreglo a mi conciencia y a los consejos tomados de padres espirituales"-, hace constar que todos los bienes los había adquirido con su industria y la buena dirección de su difunta consorte, "sin necesitar más que sus criados que obedeciesen sus buenas ordenes que se estendían a un cuidar de los hijos y nietos que hemos tenido en nuestra compañía, lo que así declaro

\footnotetext{
${ }^{50}$ Para los otros hijos Jerónimo había sido el autor, pues haber otorgado un "instrumento tan dilatado y de tanta recomendación y autoridad en una berlina... con el apuro y desorden que se nota que no se a oido ni es regular que acontezca en ninguna última disposición". ARCHVa, RE, caja 3598-05, ff. 41v.-42.
} 
para que ninguno ni alguna de nuestras hijas se atribuyan méritos sobre este asunto ni pidan por lo mismo recompensa". No obstante, añade que la presencia de su hija doña María "no ha dejado de ser bastante para contribuir a ello para cuidarnos con el amor que corresponde", y en consideración a este trabajo no se le pediría cosa alguna en razón de su manutención, pero sí por la de sus hijos, que se le rebajaría de su haber. Asimismo, en reconocimiento a lo mucho que les había cuidado, manifiesta también su deseo de darle 1.500 reales por lo que había llevado cuando enviudó y la ropa de su uso, sin inclusión de las alhajas, lo mismo que a su hijo don Andrés, "obediente siempre a mis preceptos". Revoca los 17.000 reales de mejora a Josefa, "porque no ay méritos particulares y que excedan a los demás mis hijos", y si no fuese posible, concede a cada uno de sus hermanos otros tantos; añade, además, que se le descuenten otros 4.000 reales por distintas cosas que el matrimonio recibió de él y de su esposa, bajo la amenaza de desheredarla en el tercio y quinto de sus bienes en caso de no aceptarlo. Por lo que respecta al resto de los hijos, recuerda las deudas de Francisco (16.822 reales hasta 1780) y de Jerónimo (18.000 reales) y manifiesta su deseo de que se abone a éste último lo gastado en las gestiones del vínculo por haberlas hecho siguiendo sus órdenes. Nombra a Jerónimo como único albacea, y en su defecto al hermano que le siga en edad, pero antes añade que si hay alguna duda para ejecutar el testamento la resuelva también ese hijo, acompañado de un hombre docto, confiando "de su buen corazón y prudencia de que tengo sobradas pruebas se hará lo más justo y como hermano mayor servirá de padre".

Para evitar que este testamento fuese derogado si en un futuro se veía obligado a firmar otro contra su voluntad, como ya ocurrió con su esposa ${ }^{51}$, se incluyó una cláusula reservada a la que se debía aludir necesariamente para suprimir su validez, que consistía en "referir al pie de la letra de como está en el catecismo los frutos del Espíritu Santo y las virtudes cardinales con más los años y días mismos y los del presente otorgamiento, testigos de él y escribano". Este temor se hizo realidad unos meses después, pero de momento el día transcurrió con alegría: después de dar una vuelta al nuevo plantío de San Francisco, fue a la casa de Jerónimo donde le esperaban los demás hijos, y allí comieron y bebieron juntos y se divirtieron un rato.

Pasados unos meses los dolores y enfermedad de Andrés García de Quiñones se agravaron. Le administraron entonces el viático, se confesó repetidas veces y le aplicaron cuatro parches de cantáridas, esperando su muerte de un momento a otro, pero su fuerte naturaleza le permitió resistir otros dos meses. Los cirujanos de cabecera, Tomás Sendín y José Sisi, le aplicaron las cantáridas tres o cuatro veces más y tuvo a su lado constantemente a padres capuchinos con los que poder descargar su conciencia, pero nada dijo en todo este tiempo del nuevo testamento ni mostró preocupación alguna por él. Debido a la gravedad de su estado nunca se le dejaba sólo, alternándose por las noches los familiares con los amigos. El 11 de noviembre de 1784 se quedó en la casa Ramón Sánchez, que sabía del documento por haber sostenido el tintero para su firma, y en un desliz aludió al mismo en presencia de la familia y los criados. La noticia causó la consiguiente conmoción y faltó tiempo a los que vivían con él para intentar conseguir su nulidad. De madrugada comenzaron a presionarle como ha-

${ }^{51} \mathrm{Al}$ parecer había muerto "llamando a su hijo Jerónimo y con otras demostraciones que manifestaban la inquietud de su corazón por las anteriores disposiciones". AHPSa, Protocolo 3980, f. 779. 
bían hecho para la firma del codicilo y aprovechando que durante el paseo del nuevo rector por las calles nadie acudiría a la casa, llamaron al escribano Anieto y en presencia de Andrés, Mํㅡㄹ Eugenia y Josefa, de los hermanos y madre de Soporta y del carpintero Pedro Melgar, que acudía allí todas las tardes a merendar, incorporaron a Andrés García de Quiñones para que firmase un pliego de papel sellado en blanco, sin que se escribiese allí nada ni se leyese cláusula alguna, tal como reconocieron los testigos y confesó el propio escribano, que se encargó de rellenar después el folio.

Así surgió la declaración del 12 de noviembre de $1784^{52}$ en la que tras acusar a Jerónimo de haberle engañado, ratificaba la validez del testamento de 1778 y del codicilo de 1780 con el deseo de tranquilizar su conciencia ante la certeza de una muerte inminente, como si después de meses de gravedad extrema sólo entonces la hubiese presentido. Este testimonio aislado de su contexto y antecedentes es el que hasta ahora se conocía, ofreciéndonos una visión parcial de los hechos y dándonos de Jerónimo García de Quiñones una imagen de hijo intrigante, ambicioso y sin escrúpulos que no corresponde a la realidad ${ }^{53}$. Lógicamente los perjudicados por el cambio no podían menos de acusarle de haber dispuesto "toda la maquinaria del referido testamento", y en eso sin duda llevaban razón, pero tampoco cabía quedarse impasible viendo las artimañas con que aquellos habían procedido para cambiar sucesivamente en su favor lo establecido en el testamento de 1777.

Andrés García de Quiñones murió a los tres días de esa declaración, en la noche

52 AHPSa, Protocolo 5871, ff. 298-299. ARCHVa, RE, caja 3598-05, f. 36.

${ }^{53}$ A. ROdRíGuez G. DE CEBALlos, art. cit. p. 41 del 15 de noviembre de $1784^{54}$, cuando menos lo esperaban. Nada más enterarse de la noticia, el corregidor mandó que el escribano Agustín Manuel de Anieto se presentase en la casa mortuoria y recogiese todas las llaves para hacer prevención de inventario. Sin embargo, al día siguiente Jerónimo García de Quiñones solicitó, como único testamentario de su padre, que todas las diligencias se llevasen a cabo en el oficio de don José Manuel López, ante quien aquél había otorgado las últimas disposiciones testamentarias, y que un cerrajero asegurase bien la habitación en la que debían meterse todos los bienes, como así se hizo ${ }^{55}$. Se inició entonces un largo pleito entre los hermanos: de un lado Jerónimo con poderes de Antonio Cándido y Francisco, y del otro Ma Eugenia, Andrés y José López Sopuerta, en representación de su mujer Joaquina. La cuestión principal del enfrentamiento era la validez o nulidad del testamento otorgado por Andrés García de Quiñones el 27 de abril de 1784, que condicionaba de manera decisiva la división de la herencia. Después de muchas diligencias, de recusaciones de escribanos e incluso de jueces, el alcalde mayor de Salamanca ordenó el 1 de agosto de 1785 repartir los bienes muebles que se habían inventariado $\mathrm{y}$ tasado judicialmente, a partes iguales entre los seis interesados, llevándose todos de lo bueno y lo malo, y sólo admitió la apelación interpuesta por $\mathrm{M}^{\mathrm{a}}$ Eugenia, Andrés y José López Sopuerta en cuanto a efectos devolutivos, no suspensivos. Inme-

\footnotetext{
${ }^{54}$ ADS, 423/26, f. 269v. Fue enterrado junto a su esposa en la sepultura de San Isidoro. Según el cirujano Tomás Sendín contribuyó a la muerte el haberle mudado de ropa limpia contra su dictamen. ARCHVa, RE, caja 3598-05, f. 37v.

${ }^{55}$ Sólo quedaron fuera de la sala principal donde se incluyeron, las camas y otros bienes para uso de los que vivían en la casa, pero Jerónimo pidió que se hiciese una relación de los más principales. ARCHVa, RE, caja 3598-05.
} 
diatamente recurrieron éstos la sentencia ante la Chancillería, acusando de falta de neutralidad a los jueces por la amistad que tenían con la parte contraria, pero el alto tribunal ratificó el auto del alcalde, ordenando el 23 de agosto de 1786 que el reparto se hiciese ante el escribano don Antonio Bernardo Peti separando solamente las ropas de vestir y de uso de Ma Eugenia y Andrés, pero no las alhajas que reclamaban también como suyas.

Un año después, el 21 de julio de 1787 el nuevo corregidor don José Oliveras y Carbonell dictó sentencia con respecto a los testamentos: reconoció la validez del otorgado el 27 de abril de 1784, por ser muy conforme al que "con igual libertad se otorgó en 1777", y declaró ilegítima la declaración de 12 de noviembre del mismo año, condenando al escribano Anieto, ante quien se había realizado, a pagar una multa de 20 ducados por no haber cumplido las formalidades de derecho, y amenazándole con privarle del oficio si reincidía en estas nulidades. Como era de esperar, la parte perjudicada apeló de nuevo ante la Chancillería. Este tribunal dictó sentencia definitiva el 13 de marzo de 1789 declarando nulos todos los testamentos excepto el de 29 de octubre de 1777, posiblemente por considerar que en los siguientes los otorgantes habían sido de algún modo coaccionados; mantuvo, sin embargo, la condena impuesta por el corregidor al escribano Anieto. No contentos con la resolución, $\mathrm{M}^{\mathrm{a}}$ Eugenia, Andrés y José López Sopuerta volvieron a reclamar la validez del testamento otorgado en 2 de agosto de 1778. Se sucedieron de nuevo acusaciones de haberse apropiado unos y otros de dineros y objetos de sus padres, y declaraciones al respecto de José López Sopuerta y Jerónimo García de Quiñones, pero la real Chancillería ratifico de nuevo la sentencia el 22 de diciembre de 1790 y dio carta ejecutoria para su cumplimiento en 18 de abril de $1791^{56}$.

Después de más de ocho años de discordias, durante los cuales murieron Antonio Cándido y su hermano Andrés, y de haber gastado mucho dinero en los pleitos que se sucedieron ${ }^{57}$, los herederos de Andrés García de Quiñones decidieron finalmente olvidar sus antiguas rencillas y sentarse a negociar un acuerdo amistoso para repartir los bienes raíces que constituían la parte principal de la herencia, dado que los bienes muebles ya se habían distribuido atendiendo a las órdenes superiores. Teniendo en cuenta la mala experiencia anterior, en este caso la tasa y la división la realizaron ellos mismos de manera extrajudicial, liquidando además las cuentas que tenían pendientes entre sí y reconociendo lo recibido por cada uno en legítimas. Antes de proceder al reparto pagaron las deudas de la testamentaría todavía pendientes, rebajaron unas cantidades por distintos aniversarios que cargaban sobre algunas propiedades y prescindieron de aquellas que se consideraban ya incobrables, como eran los 362.821 reales que debía la real Hacienda ${ }^{58}$.

También se descontaron de los bienes de la testamentaría 6.000 reales que se dieron a Jerónimo García de Quiñones, para que, como hijo primogénito y sucesor del vínculo perteneciente a su padre en la villa de Villafranca del Bierzo, continuase

56 ARCHVa, RE, 3598-5.

${ }^{57}$ Lo gastado por Jerónimo, Antonio Cándido y Francisco superó los 16.000 reales, que prestó a su suegro don Antonio Reyrruard reintegrándoselos Jerónimo García de Quiñones con las once tierras de Villoria que le tocaron en herencia. AHPSa, Protocolo 5774 , ff. 679 r.-680v.

${ }^{58}$ Esta era la cantidad precisa que se anota en el reparto, aunque en los sucesivos testamentos Andrés García de Quiñones señala exclusivamente 360.000 reales. 
las gestiones para recuperar las propiedades del mismo, tal como había sido el deseo de aquél, quedando el resto de los hermanos a partir de este momento libres de la obligación.

La reivindicación y restitución de este mayorazgo fue un asunto que sin duda inquietó a Andrés García de Quiñones desde comienzos de los años setenta y que no tuvo la satisfacción de ver resuelto. No se trataba, como ha señalado Rodríguez de Ceballos, de obtener carta de hidalguía ${ }^{59}$, sino de reivindicar unos bienes usurpados. Por parte de su madre, doña Josefa Quiñones, le correspondía el derecho sucesorio al vínculo instituido en Villafranca del Bierzo por el clérigo don Francisco Rodríguez en su testamento de 3 de julio de 1694. Estaba compuesto por varios bienes raíces que había adquirido después de ser sacerdote: una casa en la calle de la Estafeta (colación de la parroquia de Santa Catalina), dos viñas y cuatro huertos, que deberían permanecer unidos. A su fallecimiento dejó como poseedor del vínculo a su hermano don Juan Quiñones, casado con María Álvarez, a quien sucedería en los bienes su hijo don José Quiñones y, en caso de faltarle heredero legítimo, la mayor de las hijas, que era Josefa Quiñones Álvarez, y sus hijos e hijas. El fundador excluyó de manera expresa de la sucesión del vínculo a cualquier religioso o religiosa, de cualquier orden. El mayorazgo pasó en un primer momento de don José Quiñones a su hijo del mismo hombre, pero cuando éste decidió ingresar en la Compañía de Jesús otorgó previamente escritura, con fecha de 5 de septiembre de 1764, por la que dejaba como usufructuarias del vínculo a sus tías solteras doña Rosa y doña Francisca, y cuando falleciesen a doña Manuela Quiñones, casada con don Pedro Núñez Castelo, y a sus

${ }^{59}$ A. Rodríguez G. De Ceballos, art. cit. p. 41. Cf. ARCHVa, RE, caja 3390/25. hijos. Durante años Andrés García de Quiñones consintió en que su tía Rosa Quiñones gozase de esos bienes, pero en 1772 decidió reclamar la pertenencia del vínculo del que era heredero directo a través de su madre, al haber quedado excluido del mismo don José Quiñones en el momento de hacerse jesuita, pese a haber dispuesto del mismo sin tener facultades para hacerlo. Ninguna objeción puso al respecto su tía Rosa y por auto de 9 de noviembre de ese año Jerónimo García de Quiñones, en representación de su padre, tomó oficialmente posesión en Villafranca del Bierzo de la casa en que vivía aquella paseándose por las distintas estancias.

Sin embargo, a esta posesión se opuso judicialmente Pedro Núñez Castelo, alegando que debía legitimar su persona a la sucesión y, sobre todo, acreditar la muerte del jesuita o que había profesado para no poder volver jamás al siglo, algo que no podía esperarse desde el momento en que el Papa había extinguido la Compañía y sus miembros habían quedado como seglares o sacerdotes, que el fundador no excluyó de la sucesión al vínculo. Ante contradicciones tan poco consistentes, la real Chancillería de Valladolid, ante la que apeló Núñez Castelo, dio la razón a Quiñones y por auto de 20 de julio de 1775 ratificó el del alcalde de Villafranca dándole la posesión del vínculo, con pena de 50 ducados a quien lo perturbase. No obstante, en la ejecutoria de 24 de octubre de 1775 la Chancillería admitió la reclamación de Castelo en cuanto a que la casa sobre la que Quiñones había tomado posesión, situada en el barrio bajo del Campo de Clariago, no correspondía a la del vínculo ${ }^{60}$. El problema era que con el

${ }^{60}$ El propio Andrés García de Quiñones acudió el 19 de noviembre de 1774 a Villafranca en compañía de Nicolás Carrero, vecino de Avilés, y entró en los huertos ampliando la posesión de la casa tomada dos años antes por su hijo Jerónimo. Sobre este pleito, ARCHVa, 
tiempo algunas propiedades del mayorazgo se habían vendido y se habían confundido los límites de otras. Esto obligó a Quiñones a proseguir las reclamaciones ante la Chancillería, sin que ocho años después de su muerte se hubiesen podido recuperar los bienes que se había mandado entregarle en 1775, pese a haber gastados gran cantidad de dinero en gestiones y pleitos ${ }^{61}$.

En todo caso esos bienes, de recobrarse, sólo pertenecerían al primogénito, de manera que quedaron excluidos del reparto que llevaron a cabo los hermanos el 5 de abril de 1793. Sólo después lo hicieron oficial otorgando el 28 de ese mismo mes la escritura de concordia, transación, partición y división de bienes ${ }^{62}$. Según esa tasa, una vez deducidas las deudas el cuerpo general de la hacienda de Andrés García de Quiñones ascendía a 290.529 reales y 26 maravedíes, incluidas las distintas cantidades recibidas por cada hijo en concepto de legítimas, que sumaban $111.302,16$ reales ${ }^{63}$. A cada uno de los seis hermanos le correspondió, por tanto, 48.421,21 reales, además de los 3.785,18 que ya habían recibido en bienes muebles, tasados en 22.713,17 reales.

RE, caja 3390-25 y caja 3166-3.

${ }^{61}$ En el testamento de 1778 Quiñones declara que todavía no había logrado cobrar las rentas y reconocer las propiedades del vínculo, aunque para su seguimiento su hijo Jerónimo había gastado en los viajes y litigios realizados por su orden, más de 8.000 reales. En esta ocasión indica que no debía reclamar estas cantidades por repercutir en su beneficio, pero en el testamento de 1784 considera que debían pagarse del común de bienes y proseguir con las gestiones hasta que se hiciese efectiva la ejecutoria. Hay poderes para seguir el asunto en 1779. ARCHVa, RE, caja 3598-05. AHPSa, Protocolo 5768, ff. 677-678.

${ }^{62}$ La escritura, seguida de la partición de bienes, se encuentra en el oficio de José López Sopuerta, pero la firma el escribano Agustín Zaragoza Godínez. AHPSa, Protocolo 5774, ff. 632-635 y 636-678.

${ }^{63}$ Según el acuerdo al que llegaron Jerónimo había recibido de legítimas 18.500 reales, $M^{\mathrm{a}}$ Eugenia 11.248,25, Antonio Cándido 4.000; Francisco 29.660; Andrés 5.893,25 y Josefa 42.000 reales.
Los más de 310.000 reales en que se valoraron los bienes muebles y raíces, muestra el notable enriquecimiento logrado por Quiñones al final de su vida, sobre todo teniendo en cuenta sus escasos recursos iniciales e incluso los que tenía en 1753, cuando se hizo el Catastro, a pesar de ser el arquitecto salmantino que recibía entonces los ingresos fijos más elevados ${ }^{64}$.

Este bienestar económico resulta aún más significativo si lo comparamos con otros arquitectos instalados en la ciudad. En esas fechas sin duda el que gozaba de mayor prestigio y posición en Salamanca era don Juan de Sagarbinaga. En 1791 tenía capacidad para prestar a la Compañía de Paños y Joyas 80.000 reales, sin embargo cuando en 1798 se inventariaron sus bienes tras su muerte, ocurrida el 18 de diciembre de 1797, la tasa no llegó a 10.000 reales, menos de la mitad de lo que valían los bienes muebles de Quiñones. Sumados a éstos otras cantidades adelantadas a sus hijos o prestadas al vizconde de Huerta como administrador que era de sus posesiones y rebajados los gastos del funeral y entierro, el caudal total que se repartió a los herederos fue de 83.533 reales $^{65}$, es decir, unas tres

\footnotetext{
${ }^{64}$ Carecía de bienes inmuebles que le proporcionasen utilidad, pero se le calculaba un salario fijo de 21 reales, distribuidos de la siguiente manera: seis por la obra del Colegio de la Compañía de Jesús, nueve por la de la Ciudad, y seis por la del Conde Grajal, a los que debían añadirse los siete reales diarios que daba la Ciudad a su hijo Jerónimo como aparejador y los cuatrocientos que obtendría por las visitas de obras. Cf. Salamanca 1753, ob. cit. p. 217. Sus ingresos estaban entonces por encima de los de Manuel de Larra Churriguera y también superaban los de los arquitectos mejor situados en Valladolid o Burgos, como Antolín Rodríguez, Manuel Serrano, Díez de Ytuño y los hermanos Luis y Manuel Cortés del Valle. Cf. AzOFRA, E., «Precisiones biográficas sobre el arquitecto Juan de Sagarbinaga (1710-1797)», BSAA, LXXIV (2008), pp. 229-231.

${ }^{65}$ AzOFRA, E., art. cit, pp. 245-247. Los bienes del maestro de obras Francisco Álvarez, muerto en 1763, no llegaban a 24.500 reales y los de Lesmes Gabilán
} 
veces y media menos que lo acumulado por aquél.

\section{LA ACTIVIDAD EMPRESARIAL DE AN- DRÉS GARCÍA DE QUIÑONES: EL ABASTO DE MADERAS}

En buena medida el enriquecimiento de Andrés García de Quiñones habría que relacionarlo con su traslado a Galicia y el establecimiento de su residencia en La Coruña hacia 1765 . Su estancia coincidió con uno de los momentos más prósperos y de notable desarrollo socioeconómico de esta ciudad, generado por la concesión en 1764 de los Correos Marítimos con América, que supusieron su apertura al comercio con las Indias. A esta situación de bonanza también contribuyó la decisión de convertir La Coruña en meta del Camino Real de Galicia que partía de la Corte, lo que pone de manifiesto la importancia de la ciudad para la política estatal, tanto desde el punto de vista estratégico como comercial. Esta nueva condición tuvo un claro impacto urbano, iniciándose una serie de proyectos orientados a cubrir las carencias de la localidad y a mejorar los edificios y espacios públicos ${ }^{66}$.

Andrés García de Quiñones, y después su hijo Antonio Cándido, no fueron ajenos a este proceso de transformación, si bien en un principio el destino del arquitecto fue Betanzos con el fin de hacerse cargo de la construcción del Archivo General del Reino de Galicia. El edificio se mandó crear por real decreto de 2 de marzo de 1763 para custodiar la documentación emanada de la Real Audiencia y, a propuesta del Capitán

Sierra, según tasa e inventario de 1804, ascendían a 53.809 reales, a los que habría que sumar 4.578 reales de obras realizadas pendientes de cobro. AHPSa, Protocolo 3455, ff. 548-559 y Protocolo 3122, ff. 301 y ss.

66 Sobre los aspectos urbanísticos y arquitectónicos, Cf. A. Vigo Trasancos, Ob. cit. J. A. SÁNCHEZ GARCÍA, «Comerciantes y arquitectura...», pp. 177-239.
General Marqués de Croix, se pensó erigirlo en Betanzos. Ese mismo año el ingeniero militar Feliciano Míguez realizó el proyecto, que sería costeado con el impuesto de un real sobre cada fanega de sal que se consumiese en la región durante diez años, y su ejecución se sacó a pública subasta. El presupuesto inicial, que ascendía a 1.100.000 reales, fue rebajado por Andrés García de Quiñones en su postura hasta 837.000 reales ${ }^{67}$. Con todo, teniendo en cuenta el elevado precio del remate, según la práctica habitual previsiblemente se le exigiría una fianza proporcionada $\mathrm{y}$, dado que el arquitecto carecía de bienes patrimoniales y sus ingresos eran limitados, tuvo que contar con un garante lo suficientemente solvente y acreditado. La documentación disponible hasta la fecha no nos ofrece información al respecto, pero es posible que ya desde entonces Quiñones contase con el apoyo de Jerónimo Hijosa.

Hijosa es uno de los representantes más destacados de la oligarquía urbana y comercial de la Coruña del último tercio del siglo XVIII, el segundo en importancia después de Benito Agar, según la lista de 1785. Nacido en Medina de Rioseco, llegó a aquella ciudad hacia 1752. Allí formalizó sociedad con su paisano Joaquín Asensio, pero fue su matrimonio con la viuda de Rodríguez del Castillo en 1759 lo que realmente dio el empujón definitivo a sus negocios, apoyado en la fortuna de su esposa. Su capacidad económica y su espíritu emprendedor se pusieron de manifiesto en la diversificación de sus actividades mercanti-

\footnotetext{
${ }^{67} \mathrm{Al}$ parecer hubo un primer remate en Quiñones que debió repetirse por las protestas de la Junta del Reino de Galicia, no obstante los datos recogidos por los distintos autores resultan confusos y falta un estudio riguroso sobre el proceso constructivo del edificio. Al respecto, J. GARCÍA-AlCAÑIZ YUSTE, ob. cit. pp. 8890. E. FERNÁNDEZ-VILlAMIL, Juntas del Reino de Galicia, Madrid, 1962, tomo I, pp. 278-284. Palacios para un Archivo Real, La Coruña, 1995, pp. 14-15.
} 
les e industriales. No es posible dar cuenta de todas ellas, pero a título de ejemplo se podrían destacar los distintos abastecimientos (carne, vino y en especial granos) para el Ayuntamiento de la Coruña o para el Estado (en particular materiales para las fortificaciones y el astillero), la realización de numerosas expediciones comerciales con las colonias de Ultramar en navíos de su propiedad, con un elevado volumen de importaciones de cueros, azúcar o cacao, la creación de una Compañía de Seguros, la propiedad de una fábrica de harinas o diversas iniciativas en materia de pesca, siendo pionero en la aplicación de nuevas técnicas de salazón, fundador del Montepío de Pesca en Galicia y promotor de un plan de investigación pesquera nacional para experimentar en artes de captura. El incremento en sus negocios fue paralelo a su presencia en organismos públicos. Fue regidor del Ayuntamiento, Director de la Real Compañía Marítima del Puerto de la Coruña, miembro con diversos cargos del Real Consulado del Mar a raíz de su creación en 1785, diputado de la Junta de Caminos del reino, Comisario Honorario de Guerra de los Reales Ejércitos de S.M. etc. ${ }^{68}$. En los últimos años de su vida le alcanzó la crisis del comercio americano y cuando falleció en 1803 tenía numerosas deudas, a diferencia de la etapa alcista en que lo trató Andrés García de Quiñones.

El seguimiento de las obras del Archivo General, iniciado en 1764, obligó al arquitecto a trasladarse con su familia a Galicia, dada la distancia de Salamanca. No hay datos seguros sobre su terminación,

${ }^{68}$ A., MEIJIDE PARDO, «Hombres de negocios de la Coruña dieciochesca: Jerónimo Hijosa», Revista del Instituto José Cornide de Estudios Coruñeses, núm. 3 (1967), p. 85-147. L. AlONSO ÁlVAREZ, Comercio colonial y crisis del Antiguo Régimen en Galicia (1778-1818). A Coruña, 1986. A. GARCíA LÓPEZ, Los pioneros del comercio en la Coruña. Valladolid, Ed. Lex Nova, 2008, sobre Hijosa, pp. 87-101. pero debía de estar ya prácticamente concluido en 1771, porque de lo contrario no se habría permitido que el asentista se ausentase $^{69}$. El edificio nunca sirvió para la finalidad que se hizo, pero la calidad y solidez de su magnífica fábrica sin duda sirvió para aumentar el prestigiar del constructor, que ya debía de gozar de buena reputación. De hecho, en uno de los viajes que realizó Quiñones a Galicia en 1764 con motivo de esta obra, el arzobispo compostelano Bartolomé Rajoy le pidió que reconociese la fachada de la Azabachería de la Catedral para informar al respecto de su coronamiento ${ }^{70}$. Unos años después el prelado recurrió de nuevo a él para poner en marcha su idea de levantar un Seminario de Confesores, con las cárceles secular y eclesiástica a sus lados, frente a la plaza del Obradoiro, en el lugar donde con anterioridad se había previsto construir el Consistorio y para lo que ya había dado trazas en 1764 Lucas Ferro Ca-

\footnotetext{
-

${ }^{69}$ Según relación del teniente coronel de ingenieros Antonio López Sopeña, el inmueble estaba concluido en 1769, y Soraluce sostiene que se construyó entre 1763 y 1770, si bien García-Alcañiz considera que se prolongó hasta 1775 , sin datos justificativos. En octubre de 1772 el marqués de Bosqueflorido redactó el plan por el que debía regirse el Archivo, y con anterioridad se había propuesto destinar parte de la consignación destinada a la construcción para salarios de archiveros y oficiales, lo indica que las obras estaban prácticamente terminadas. Por real orden 22 de octubre de 1775 se dispuso destinar el edificio a cuartel y utilizar como archivo la sala de Discordias y las piezas inmediatas a ella en el palacio de la Capitanía General y Audiencia de La Coruña, para lo que se pidió a Antonio Cándido García de Quiñones que proyectase las reformas necesarias. J. R. SORALUCE BLOND, Castillos y fortificaciones de Galicia. La arquitectura militar de los siglos XVI-XVIII, A Coruña, 1985, p. 122. J. García-AlCañiz Yuste, ob. cit. pp. 88-90. C. VAAMONTE LORES y S. DAVIÑA SÁINZ, «Efemérides de la ciudad de Betanzos», Anuario Brigantino, núm. 31 (2008), p. 219.

${ }^{70} \mathrm{El}$ cabildo le pagó por esto tres doblones de a ocho el 29 octubre de 1764. J. GARCíA-ALCAÑIZ, ob. cit. 128 y 212. R. OTERO TÚÑEZ, «Rajoy, constructor», Cátedra. Revista Eumesa de Estudios, núm. 8 (2001), p. 65.
} 
veiro, uno de los arquitectos más afamados de la ciudad. En abril de 1766 el prelado envió el plan de Quiñones al Consejo de Castilla para su conocimiento, pero ante la petición dirigida por el Ayuntamiento a Rajoy, en agosto de ese mismo año el maestro salmantino hizo un nuevo proyecto de planta asimétrica para incluir el edificio del consistorio adosado a un lado. Sin embargo, ante la denuncia del administrador del Hospital Real de que el nuevo Seminario perjudicaría a su edificio, en febrero de 1767 el Consejo ordenó suspender las obras iniciadas y, para zanjar la cuestión, pidió al Capitán General que designase a un técnico. El ingeniero francés Carlos Lemaur se hizo entonces cargo del asunto; aceptó el perímetro general y la extensión de la última planta diseñada por Quiñones en septiembre de 1766, pero replanteó por completo la fisonomía del edificio en un lenguaje barroco-clasicista con detalles rococó muy del gusto francés ${ }^{71}$. Al parecer el arzobispo Rajoy volvió a a proponer a Andrés García de Quiñones en 1769 para convertir el Cuartel del Campo de los Sapos en un Hospicio para pobres y quizá pensó en él para reformar su casa en Puentedeume ${ }^{72}$, pero como ya había sucedido en Ciudad Rodrigo y el Fuerte de la Concepción, su protagonismo como arquitecto quedó en un segundo plano ante el peso de los ingenieros militares. En consecuencia, se tuvo que contentar con la función de asentista, convirtiéndose en una especie de empresario de la construcción, capaz de contratar va-

${ }^{71}$ A. VigOS TRASANCOS, «La intervención del estado dieciochesco en la arquitectura gallega de iniciativa privada: el papel de los ingenieros y la obra de Carlos Lemaur», en Cuadernos de Estudios Gallegos, XL, 1992, pp. 115-133.

72 A. Vigo TRASANCOS, «El arzobispo compostelano Bartolomé Rajoy y Losada (1771-1772). Gusto artístico y mecenazgo arquitectónico», Norba-Arte, núm. 13, 1993, pp. 134 y 138. rias obras al mismo tiempo, algo por otra parte habitual.

Así, en 1767 se ofreció para construir las nuevas Casas Consistoriales de la Coruña, según el proyecto del académico Ventura Rodríguez. Aunque finalmente dificultades con los propietarios de los solares impidieron que se iniciase en ese momento ${ }^{73}$, presumiblemente Andrés García de Quiñones no tuvo ninguna dificultad para encontrar fiador, tanto más cuando en esas fechas se había convertido ya en socio de Jerónimo Hijosa al menos en un asiento suscrito con el Estado. Ellos dos, junto con los maestros de obras locales Francisco Antonio Zalaeta y Alberto Ruidal ${ }^{74}$, tomaron a su cargo de mancomún y por cuartas partes el asiento general para el suministro de materiales para las reales obras de fortificación de la Coruña, El Ferrol y demás puertos de Galicia. Sabemos que Hijosa obtuvo por este asiento un beneficio no inferior a 20.540 reales, y posiblemente otro tanto les correspondió a cada uno de sus socios ${ }^{75}$.

73 A. Vigos TRasancos, A Coruña y.., op. cit. pp. 149-151. Cuando en 1771 estaba previsto emprender la construcción, el asentista Antonio Vicente Paz tuvo problemas para entregar la fianza, por lo que hay que suponer que Quiñones contó con ella en su momento.

${ }^{74}$ Francisco Zalaeta, además de realizar en 1763 el proyecto inicial para las nuevas Casas Consistoriales, entre otras obras contrató en 1758 la construcción del edificio de la cárcel por 487.500 reales, y entre 1764 a 1767 se hizo cargo del largo andén de la Marina, bajo la dirección y los planos del ingeniero Pedro Torbé. Por lo que respecta a Ruidal intervino en la Coruña en la construcción de la iglesia de San Nicolás (17581760), en el arreglo del guardamar de Santa Lucía (1764-1765), en la tasa del teatro Setaro o en el enlosado de la plaza de la Aduana en 1786. A. VIGO TRASANCOS, A Coruña y.., op. cit., pp. 122-125, 146, 149-151 у pp. 102, 143, 161-163, 230.

75 Citado por MeIJIDE PARDO, A., art. cit., p. 128. J. A. SÁNCHEZ GARCíA -«Maestros de obras y aparejadores....», art. cit. p. 178- considera que fue Antonio Cándido quien formó la compañía, pero no hay base para suponerlo, mientras la documentación avala la estrecha relación entre su padre y el acaudalado co- 
Además de lo ya conocido, hay constancia de que Andrés García de Quiñones realizó un primer proyecto y condiciones para ampliar el edificio de la Aduana, situado en la pequeña plaza regular, abierta al mar, que presidía el largo andén de la Marina construido en la década de $1760^{76}$. Según la representación enviada al rey por varios comerciantes, entre los que figuraba Jerónimo Hijosa, era necesario levantar nuevos almacenes para el depósito y registro de los géneros que se embarcaban y desembarcaban en la Aduana porque al haber aumentado considerablemente el comercio con América el existente se había quedado pequeño. A tenor del diseño y las condiciones firmadas en 20 de abril de 1769, la intención era disponerlos en un costado del edificio actual, desde la plaza de la Marina hasta la calle paralela, para lo que sólo habría que trasladar a otra parte de la ciudad la pequeña capilla del Santo Cristo situada junto a ésta. La longitud sería igual al inmueble de la Aduana, pero se le daría mayor anchura, de manera que su coste podía ascender, según cálculo del arquitecto, a 29.000 reales, pese a ser muy sencillo. La ampliación no se llevó a cabo en este momento, pero en 1780 fue su hijo Antonio Cándido el encargado de dirigir la construcción ${ }^{77}$.

\footnotetext{
merciante.

${ }^{76}$ Sobre este proyecto realizado a partir de planos del ingeniero Pedro Torbé, Vigo Trasancos, A., A Coruña..., op. cit. pp. 146-147.

77 AGS, Dirección General de Rentas, 2 $2^{\mathrm{a}}$ remesa, leg. 510 y M. P. y D 11, 161. Antonio Cándido había presentado dos propuestas, una similar a la de su padre, que suponía la supresión de la capilla, y otra que la mantenía incorporando terreno de la plaza de la Marina como compensación. A finales de siglo la Aduana volvió a ser ampliada con la compra de propiedades inmediatas y se le dio la actual apariencia, según diseño del arquitecto José de Elejarde. AGS, Dirección General de Rentas, leg. 510 y 954. J. A. SÁNCHEZ GARCíA, «Comerciantes...», art. cit. p. 230. A. Vigo TRASANCOS, A Coruña..., op. cit., pp. 207-211.
}

Más importantes que las intervenciones arquitectónicas que pudo llevar a cabo en Galicia, debieron ser las relaciones que entabló con la burguesía mercantil, que orientaron su actividad hacia los negocios, buscando quizá un ascenso social. Lo cierto es que una vez concluido el contrato para el suministro de materiales de fortificación, Andrés García de Quiñones se embarcó en un nuevo asiento para la Real Hacienda, consistente esta vez en el suministro de madera de construcción del Principado de Asturias para los astilleros y arsenal de El Ferrol.

El aprovechamiento de los recursos forestales asturianos se intensificó fundamentalmente a partir de 1760, ante el agotamiento de los montes santanderinos. En estos años se planteó la explotación del extenso monte de Muniellos, situado en el concejo de Cangas de Narcea y perteneciente al conde de Toreno, en el que predominaban los robles, pero contaba también con tejos, acebos, hayas, abedules y otros árboles en los niveles inferiores. Con este fin, en 1765 se iniciaron unas costosas obras de infraestructura, dirigidas por el arquitecto Pedro Lizardi, ya que para llegar a este monte había que abrir caminos por lugares difíciles dada la orografía montañosa del lugar y, sobre todo, hacer navegable el Narcea, para poder introducir barcas planas que trasladasen la madera desde Cangas de Narcea al puerto de San Esteban de Pravia donde se embarcaba. Asimismo se procuró acondicionar el Navia y el Sella. Cuando ya se había invertido un millón de reales, a finales de 1769 el constructor naval del arsenal de El Ferrol, Francisco Gautier, ofreció una valoración negativa de este monte y de la calidad de su madera, pero a pesar de la decepción inicial que provocó su informe técnico en el Departamento de Marina, siguió explotándose y frente a su opinión de que Asturias no produciría más 
allá de los 250.000 codos cúbicos, de 1773 a 1787 se sacaron de allí $440.000^{78}$.

Las talas en Muniellos parece que se iniciaron en 1768. El primer asiento debió de correr a cargo de José Antonio Méndez Pola, vecino de Luanco, y don Juan González Pola, pues en el plan de condiciones redactado por el ingeniero director en 4 de enero de $1771^{79}$ se especifica que el empresario debía proveer de robles, hayas, nogal, castaño, álamo, fresno, aliso y duelas, de acuerdo con unas determinadas dimensiones, satisfaciendo el valor de los árboles, su derribo, labra, tira y conducción al astillero en los términos que lo ejecutaban aquellos. Según ese mismo plan, con más de doce apartados, las cortas se efectuarían en los montes de Muniellos y otros inmediatos, pero si en estos parajes no hubiese nogal, haya o castaño se les señalaría otros procurando no perjudicar a los dueños. Correspondería al asentista abrir el camino de entrada a Muniellos y los que necesitase en otros parajes para extraer el material, y asimismo se obligaba a reparar y mantener en uso los caminos y la navegación del Narcea sin reclamar nada a la Real Hacienda. Ésta nombraría contramaestres o facultativos que se ocuparían de marcar los árboles de buena calidad y de dirigir la corta y labra, excluyendo las piezas inservibles o en mal estado y siendo por tanto los responsables de que todas las que llegasen al arsenal fuesen de calidad. El número, las clases, dimensiones y circunstancias de toda pieza se ajustarían al correspondiente reglamento y a las notas que recibiría

78 J. OCAMPO SUÁREZ-VALDÉZ, Campesinos y artesanos en la Asturias preindustrial (1750-1850), Gijón, Silverio Cañada, 1990, pp. 52-54. J. P. MERINO NAVARRO, La Armada Española en el siglo XVIII, Madrid, 1981, pp. 232-237. J. LÓPEZ ÁlVAREZ, «La explotación del Monte de Muniellos (Asturias), 1763-1973», Ería, 58 (2002), pp. 273-286.

${ }^{79}$ AGMS, Pleitos, leg. 652, pieza primera, ff. 34-37. anualmente el asentista del material que hubiese de cortarse. El empresario por su parte debería buscar toda clase de operarios, ganado y lo que considerase necesario para cumplir su obligación. Para hacerse cargo del asiento se exigía una fianza de diez mil ducados (110.000 reales), la mitad en dinero y la otra mitad en bienes.

Este plan establecido por la Real Hacienda se publicó en distintos parajes de Galicia y el Principado. En 22 de marzo de 1771 Andrés García de Quiñones "y compañía" presentó en el Ferrol un memorial dirigido al Intendente General de Marina en el que señalaba los precios por codo cúbico y las condiciones con las que estaba dispuesto a hacerse cargo de este abasto, "a fin de continuar mi mérito en servicio de su majestad". Solicitaba poder extraer madera libremente de todos los montes comunes, de particulares o comunidades si no había suficiente en los señalados, siempre con el reconocimiento del contramaestre, y que se le facilitase la introducción de las chalanas donde hubiese agua suficiente y el paso por las heredades y prados con ganado y carros donde fuese necesario, con la obligación de satisfacer los daños causados por ello. Pedía que se le abonasen todas las maderas embarcadas en el puerto de salida, aunque no llegasen a su destino por un posible apresamiento de enemigos o en razón de naufragios. Establecía que la tesorería le pagase mensualmente y que una vez concluido el asiento se recibiesen en el astillero las maderas que todavía le quedasen en los montes y caminos si cumplían lo establecido, corriendo él con el gasto de la conducción. Finalmente solicitaba que tanto él, como sus compañeros y dependientes pudiesen gozar el fuero de Marina. Los precios en reales por codo cúbico que propuso inicialmente eran los siguientes: 


\begin{tabular}{lrrrrrr}
\hline Monte de Muniellos & Roble & Haya & Álamo & Fresno & Aliso Castaño \\
\hline Tablonería de todas clases & 80 & 54 & & & & \\
\hline Pieza para tamboretes, motonería y otros fines & 64 & & & & & \\
\hline Toda pieza o tablazón & & & 64 & 64 & 54 & 60 \\
\hline Duelas & 4 & 3 & & & & \\
\hline Remos de 24 a 28 pies de largo, 26 rs.; de 20 a 24 pies: 20rs; de 16 a 20: 14rs.; de 10 a 16: 9 rs & & \\
\hline Montes de Leprosa, Jurado e inmediaciones & & & & & & \\
\hline Toda pieza de construcción de navíos y tablón & 60 & & & & \\
\hline Piezas para fragatas & 51 & & & & \\
\hline Piezas para paquebotes y lanchones & 48 & & & \\
\hline
\end{tabular}

El primer remate se efectuó en el Real Astillero de Esteiro el 28 de abril de 1771 y en esa ocasión el arquitecto bajó en dos reales el precio de cada codo cúbico en todas las maderas con respecto a su oferta inicial. Quince días después, el 14 de mayo, tuvo lugar el segundo remate y en esta ocasión se presentó también don Juan Benito González de Arango, vecino de la villa de Cudillero, en el Principado. Andrés García de Quiñones hizo nueva baja de una décima en todas las clases de maderas, duelería y remos sobre los segundos precios y, como no hubo quien lo mejorase, se le adjudicó a él el asiento bajo las condiciones establecidas. Fuera ya de hora don Pedro José de Bustillo rebajó el precio media décima, pero por Real Orden de 7 de junio de 1771 no se admitió la propuesta ${ }^{80}$, por lo que el día 20 de ese mismo mes se cerró el contrato con Quiñones, por cuatro años. No obstante, debió de seguir proporcionando maderas con posterioridad, hasta comienzos de 1777, pues se habla de una importante porción adicionada a la obligación inicial $\mathrm{y}$ entre la documentación que guardaba cuidadosamente, además de los legajos de cuentas y pertrechos correspondientes a los

${ }^{80}$ Archivo General Militar de Segovia (AGMS), Pleitos, leg. 652, ff. 37-44. años 1772 al 1775, había "seis ataduras de papeles relaciones de los gastos hechos en dicho asiento en los años de mil setezientos setenta y seis, setenta y siete". Como declara en su testamento de 24 de abril de 1784 el fiador fue su "amigo" Jerónimo Hijosa y como tal a él le correspondía la mitad de los 360.000 reales que todavía en esa fecha les estaba debiendo la Real Hacienda ${ }^{81}$, pero también debían deducirle la mitad de los gastos de los pleitos que contrajo por este motivo que ascendían a 20.000 reales. Con Hijosa mantuvo una abundante correspondencia durante varios años, que guardaba en cinco legajos ${ }^{82}$.

Para poder cumplir adecuadamente su obligación Andrés García de Quiñones dejó la Coruña y se trasladó con su familia

${ }^{81}$ ARCHVa, RE, caja 3598-05, f. 19. Lo adeudado por la Real Hacienda debía corresponder a esta "madera adicionada, su relabra y excesos del montazgo" del último asiento, para cuyo cobro otorgó poder en 11 de enero de 1783 a don Benito García de Acebei, residente en El Ferrol (AHPSa, Protocolo 5770, f. 482). Al hacer el inventario se señala que "los expresados papeles concernientes a dicho asiento de maderas en sus rotulaciones tienen la expresión de ser inútiles y los interesados así lo manifestaron, pero que sin embargo era necesario conservarlos para su resguardo por lo que pueda ocurrir".

${ }^{82}$ AHPSa, Protocolo 3980, f. 776 y ARCHVa, RE, caja 3598-05, f. 19. 
a Asturias, instalándose en Avilés. Allí, siguiendo lo que sería una práctica habitual, explotó directamente unas zonas sirviéndose de capataces y subarrendó otras a personas del lugar, como consta que lo hizo con Pedro González Valledor, vecino de La Muriella (Cangas de Narcea). Las talas sólo se realizaban durante el menguante de luna de noviembre a febrero; los troncos se transportaban dentro del bosque en carretas y se aserraban allí mismo sobre "planchas", gastando mucha madera. Las piezas grandes se conducían desde el monte de Muniellos a Cangas en dos carretones y se almacenaban hasta la época propicia para llevarlas por el río hasta San Esteban de Pravia, pues de noviembre a febrero se suspendía la tira por los hielos. En el interior del monte las labores de leñadores y carreteros eran muy duras; hubo que abrir caminos y construir puentes de madera hasta cinco se hicieron en este asiento sobre el río Muniellos, desde el "sitio de las Tablizas a entrambos ríos de la Zerezal"- que a menudo destruían las riadas. Para estos trabajos llegaron muchas gentes de fuera, sobre todo leñadores y carpinteros «vizcaínos» y carreteros montañeses que tenían ya experiencia en el transporte de piezas grandes y pesadas de madera, a diferencia de lo que sucedía con los asturianos, como señalaba el contramaestre José de Piles al conde de Toreno en carta de mayo de 1774. Sin embargo, a mediados de los 70 ya participaban en el acarreo muchos carreteros de pueblos cercanos a Muniellos, como los de Moal, que en 1775 hicieron representación quejándose del retraso en el pago de los jornales, cuando Andrés García de Quiñones se había obligado a hacerlo cada quince días $^{83}$.

-

\footnotetext{
${ }^{83}$ Para estos detalles que coinciden con el asiento de Quiñones, cf. J. LóPEZ ÁlvAREZ, art. cit., pp. 277-
} 278.
Más importante es la denuncia de estos mismos vecinos contra el arquitecto por la tala abusiva que se había realizado durante su asiento, incluso de «árboles nuevos y pimpollos tiernos, que ahora derribados en la primavera de su juventud solo sirven a compadecer a la vista" ${ }^{\prime 4}$. Y la queja no es gratuita, pues entre febrero y fines de 1773 hay constancia de que en Muniellos se derribaron 4.500 robles, que dieron 15.633 codos útiles y 8.818 inútiles como madera inservible. Y según el propietario del monte, el conde de Toreno, de 1767 a 1775 se talaron 21.449 árboles para emplear en la propia explotación ${ }^{85}$. En otros montes poco explotados hasta el momento como los del concejo de Ibis, los oficiales de Marina marcaron entre 1774 y 1775 casi 50.000 árboles. Con todo esto la imagen que dejaron los asentistas entre el pueblo no fue demasiado favorable.

No fue la única ni la principal denuncia ante el Departamento de Marina de El Ferrol que tuvo que afrontar Andrés García de Quiñones como consecuencia de este negocio. En una de ellas, que al parecer no prosperó, intentaron involucrarle en la acusación contra varios de sus subarrenda-

\footnotetext{
${ }^{84}$ Entre las razones de esas talas se mencionan: maderas "para hacer planchas para serrar la madera (cuyo número ascendería a más de diez o doze mil en el discurso del asiento pues para cada árbol que derriban para el Rey, derriban otro nuevo para hazerle la plancha); otras para facilitar mas a su gusto la rastra de la tablonería; otras para ahorrar los que planchan un levisimo y corto trabajo en no virar las piezas algún tanto más al colocarlas en la plancha; otras, para cortar más a su gusto los operarios al tiempo del derribo y labra; otras, por quedar a vezes los [árboles] que se derriban, al tiempo de caer, enredados en las cañas de los que están en pie, cortando estos, por no tener que desenredar aquellos con el hacha; otras, para hazer caminos provisionales en dicho monte; otras, para puentes sobre el río en dichos caminos; otras para carretones; y finalmente, otras para hazer bombas para conduzir la madera por el río Narzea", citado por J. LÓPEZ ÁlVAREZ, art. cit. p. 278.

85 Ibidem, pp. 275 y 278.
} 
tarios acerca del uso y aprovechamiento de la proporción de maderas que se había adicionado a la obligación inicial. Quiñones se mostró parte para defender su "persona, honor i estimación con que desempeñé el citado encargo de tal asentista, celo i desinterés con que siempre procedí" 86 .

Sin embargo, ese desinterés quedó en buena parte cuestionado en el pleito que inició el regidor de Oviedo don José Vicente Omaña ${ }^{87}$ en 1771 para que se le pagasen los perjuicios que le había ocasionado la apertura de la presa del Narcea para la conducción de las maderas del monte de Muniellos, al ser menor el rendimiento de sus molinos por el escaso cauce del río de junio a septiembre y la hierba de sus prados por falta de riego. En una primera sentencia del 6 de septiembre de 1775 el intendente de Marina de El Ferrol ordenó que la Real Hacienda le pagase un total de 18.067 reales y otros 520 el asentista por la renta anual que habían dejado de producir los prados y molinos y el coste de cerrar la presa.

No contento con esto, el 16 de octubre de 1775 Omaña apeló ante el Consejo de Guerra pretendiendo que el pago por parte de Hacienda se incrementase hasta 29.000 reales con los réditos correspondiente. Cuando parecía que el fiscal iba a confirmar la sentencia, en septiembre de 1776 consideró que se había involucrado injustamente en esta causa a la Real Hacienda y declaró nulos todos los autos realizados hasta el momento, teniendo en cuenta que en las condiciones del asiento Quiñones se había comprometido expresamente a abrir caminos sin pretender recompensa alguna y a

86 Solo conocemos al respecto el poder que da Quiñones para defenderse de esta acusación. A. RODRÍGUEZ G. DE CEBALLOS, art. cit., pp. 39-40. AHPSa. Protocolo 5768, f. 673-674

${ }^{87}$ Los datos sobre el mismo en AGMS, Sección Pleitos, leg. 652. satisfacer a los dueños el daño que causare por la introducción de chalanas o la entrada por las heredades y prados con ganado y carros. Es más, a juicio del fiscal del Consejo de Guerra la condena a la Real Hacienda se había realizado con la "tarciturnidad" del empresario, que no practicó diligencia alguna ni apeló la sentencia en la parte que le condenaba, lo que acreditaba que conocía su responsabilidad en todos los perjuicios. Asimismo le acusa de haber sido tan lucrativo el asiento que había bajado voluntariamente una décima de todos los precios que previamente había señalado para cerrar la puerta a otros postores. Como consecuencia, por sentencia de 23 de octubre de 1776 el Consejo de Guerra revocó la del intendente de El Ferrol, eximió de responsabilidad a la Real Hacienda y condenó en su lugar a don Andrés García de Quiñones ${ }^{88}$. También se multó al auditor de guerra y al fiscal del Departamento de El Ferrol con 200 ducados a cada uno para que defendiesen mejor los intereses de la Real Hacienda.

A raíz de esta sentencia Quiñones, que en un primer momento había intentado mantenerse al margen alegando que no era parte en esta causa, no tuvo más remedio que intervenir. Tomando como base de su defensa la misma cláusula por la que se le condenaba, intentó demostrar que era obligación de la Real Hacienda facilitarle la

88 Debería pagar al menos 11.000 reales por la propiedad y el valor de diez eminas de pan, mitad trigo y mitad centeno, por la menor molienda, y el importe de su renta anual desde que se causó el rompimiento según los precios a los que se había vendido el trigo y centeno en el concejo de Cangas de Tineo desde 1768 a 1775; otros 5.000 por el deterioro de los prados contiguos al molino y 150 anuales hasta la entrega del capital, más otros 10.000 por el deterioro de la presa por la apertura del portillo y 300 reales en que, según peritos, se estimaba el coste anual que había tenido Omaña en repararlo y cerrarlo después del tránsito de las maderas. AGMS, Sección Pleitos, leg. 652 
introducción de chalanas en los ríos para el paso de la tablonería y es lo que había hecho el comisionado don José Piles al ordenar en agosto de 1771 el rompimiento de la presa, pagando a los operarios sin que el contratista fuese convocado en ningún momento para esto. Fue también el comisionado el que, ante las distintas reclamaciones de Omaña, dispuso que se tasasen por peritos los perjuicios ocasionados, y al asentista sólo le exigió por su contrato que pagase el importe de la menor molienda y la menor hierba de los prados, lo que siempre estuvo dispuesto a satisfacer, como lo había hecho con otros particulares por los que había atravesado sus prados con carros y ganados. Quizá viendo la debilidad de su argumento, pasó al ataque e intentó que el regidor Omaña mostrase que tenía licencia para construir una presa que perjudicaba al común impidiendo el libre uso del río. Por otra parte, frente a las acusaciones personales del fiscal, señaló que la rebaja ofrecida en los precios de todas las clases de madera no fue voluntaria "y porque su conciencia estubiese agitada de los remordimientos que le causaran el mucho lucro que iba a tener", sino obligada si quería quedarse con el asiento debido a mejora en media décima de otro postor, aunque con esa baja lógicamente no pensaba tener él pérdidas. Censuraba, finalmente, el trato de favor que siempre se había manifestado con el regidor y el rigor manifestado con el asentista, a quien correspondía ciertamente por el precio de la madera abrir y reparar el camino de entrada a Muniellos y otros que fuesen necesarios, pero su obligación no se extendía a poner navegables los ríos a su costa. Solicitaba por tanto una modificación de la sentencia, tanto en cuando a su responsabilidad, como en las partidas que debía pagar, que como mucho deberían reducirse al el importe de rehacer la presa (que ascendería a 4.700 reales) y de los perjuicios e intereses regulados anualmente en 520 reales, lo que en total sumarían 6.900 reales y no los 29.000 que se pretendía exigirle.

Esta apelación y las del auditor y el fiscal de Marina del Ferrol consiguieron tan sólo una rebaja de la condena por auto de 1 de septiembre de 1778. Andrés García de Quiñones no tuvo más remedio que pagar la renta de los prados y el molino y a través de su apoderado en Asturias, don Luis de Sama, mandó que un cantero reparase la presa $^{89}$. Obtuvo certificación de haber cumplido del subdelegado de Marina del partido de Avilés, don Andrés García Blanco, pero a juicio de Omaña se trataba de un arreglo mal hecho y superficial por lo que el 7 de marzo de 1781 nuevamente reclamó ante el Consejo de Guerra para que se exigiese al asentista la cantidad necesaria para dejar la presa en el estado original, si bien en esta ocasión no parece que prosperó su recurso ${ }^{90}$.

A pesar de este conflicto, que por otra parte se acentuó cuando ya había concluido el contrato, el resultado del asiendo de maderas en términos económicos no pudo resultar más beneficioso para Andrés García de Quiñones, incluso sin contar la elevada cantidad que quedó debiéndoles la Real Hacienda a él y a su socio Jerónimo Hijosa. Ciertamente no se le puede acusar de abusivo en su presupuesto, como insinuó el fiscal, pues en comparación con los 56 reales el codo cúbico del precio de la madera que salía de Asturias en 1769 o con los 61 ó 62 del Principado de Asturias que

\footnotetext{
${ }^{89}$ Dio poder con este fin el 6 de abril de 1779. AHPSa, Protocolo 5768, ff. 656r.-657

${ }^{90}$ Es lo que considera RodríGUEZ G. DE CEBALLOS -art.cit. p. 40- a partir de varios poderes otorgados por Quiñones en octubre de 1781 y febrero de 1782 (AHPSa, Protocolo 5768, f. 688 y Protocolo 5770, ff. 95-96), pero no tenemos constancia de la resolución. Por otra parte, su interpretación de los hechos del pleito no resulta del todo correcta dado el carácter parcial de las fuentes utilizadas.
} 
tomó el relevo en 1775, el precio medio de Quiñones, inferior a 50 reales el codo cúbico, resultaba barato. Según Merino Navarro, las cortas más importantes se hicieron en Muniellos, Cangas, Infiesto y Ribadesella y entre 1772 y 1776 suministró unos 150.000 codos cúbicos ${ }^{91}$, que supusieron un desembolso para la Real Hacienda superior a los siete millones de reales.

Viéndose enriquecido y con bastantes achaques, el arquitecto decidió dejar Avilés y regresar a su tierra junto a su hijo Jerónimo, por el que parece que sentía especial predilección. En su testamento de 27 de abril de 1784 señala de manera muy expresiva al respecto de sus ganancias: "Tragimos en dinero físico de oro metido en botes de oja de lata quinientos mil reales además de como otros diez y ocho o veinte mil que benían con separación para hir gastando de ellos, todo lo qual adquirí por el asiento de maderas que tube en Asturias para la construcción de navíos de la Real Armada y otros asientos que dirigí y en que entendí licitamente. Asimismo tragimos y deben conserbarse una servilla y bandeja mui grandes, otra serbilla y bandeja medianas, quatro docenas de cubiertos grandes con sus correspondientes cuchillos, dos salseras, dos saleros, cucharón y trinchete todo de plata y después se compró a un padre de San Gerónimo llamado fray Francisco otra servilla, un plato y dos basos de plata. Igualmente traximos el adorno de sala y demás ajuar de casa con muchos baúles, aderezos de diamantes y collares de aljofar, que todo se conservó por dicha mi consorte y su govierno" ${ }^{\prime \prime 2}$.

\footnotetext{
${ }^{91}$ J.P. MERINO NAVARRO, ob. cit. pp. 235-236 y 319
}

92 AHPSa, Protocolo 3980, f. 775v.

\section{DE EMPRESARIO A PROPIETARIO AGRARIO}

Una buena parte del capital que había amasado con el asiento de maderas, al poco tiempo de llegar a Salamanca lo invirtió Quiñones en bienes raíces o inmuebles que pudieran proporcionarle unas rentas fijas, como medio de asegurar su futuro y, por qué no, de vía de ascenso social ${ }^{93}$.

Comenzó primero comprando tierras en Villoria. Ya en 22 de septiembre de 1777 adquirió en ese pueblo, por 25.980,24 reales, nueve fincas de secano o "de pan llevar", de diferentes tamaños, que sumaban en total 24 huebras y 164 estadales $^{94}$, y apenas un mes después -el 9 de diciembre- las amplió con otra tierra de una huebra y 263 estadales que le vendió José Cascón, por $3.230,1$ reales $^{95}$. Este mismo vecino actuó como intermediario en la compra de otra propiedad de su suegra, de huebra y media, que se efectuó el 15 de febrero de 1778 en $1.668,7$ reales $^{96}$. Estas once tierras se so-

${ }^{93}$ La compra de tierras era una de las estrategias más frecuente para conseguir un ascenso social. Cf. A. MARCOS MARTíN, «Movilidad Social Ascendente y Movilidad Social Descendente en la Castilla Moderna», I. GÓMEZ GONZÁLEZ y M. L. LÓPEZ-GUADALUPE MUÑOZ, La movilidad social en la España del Antiguo Régimen, Granada, 2007, p. 27.

${ }^{94}$ Se las vendieron Manuel Ávila Hernández y Manuel González Oyos, vecinos Villoria. Sumaban en total 9864 estadales y estaban situadas en distintos lugares. Al tasarlas sus hijos redujeron su valor a 17.000 reales, muy inferior al de la compra. AHPSa, Protocolo 2885, ff. 62-65r. y Protocolo 5774, ff. 635 y ss.

${ }^{95}$ La tasa fue realizada por José Villoria Moriñigo, vecino de Aldearrubia y agrimensor aprobado, valorando la huebra de 400 estadales a 1.959 reales. AHPSa, Protocolo 3097, ff. 590-591r.

${ }^{96}$ En este caso la huebra de 400 estadales fue tasada a 1.100 reales. José Gascón recibió para este fin poder de su suegra Bárbara de Avila, vecina también de Villoria, en 14 febrero 1778 y la venta se efectuó al día siguiente, pero en Salamanca. Estas dos tierras $\mathrm{s}$ umaban en total 1.270 estadales y los herederos de Quiñones las tasaron en 3.000 reales, también muy por 
lían destinar al cultivo de cereales y para su explotación al poco de adquirirlas las entregó en arrendamiento. El 13 de enero de 1784 volvía a firmar la escritura correspondiente con un labrador de Villoruela por cuatro años, a contar desde San Martín (11 de noviembre) de 1783, a cambio de una renta anual de 14 fanegas de trigo candeal "limpio, seco y de buena calidad", que debería entregarle en torno al 15 de agosto con independencia de las calamidades de tipo climático o social que pudieran ocurrir -piedra, heladas, sequía, guerras, peste, langosta, etc. $-^{97}$.

Sin embargo, el núcleo fundamental de la hacienda de Andrés García de Quiñones estuvo dedicado a la explotación vitivinícola. La mayor parte de las propiedades que adquirió al respecto habían pertenecido al que fuera contador de Propios y de la obra de la Plaza Mayor, don Nicolás Romero del Río y doña Francisca López Pastor, como parte de su dote. Consistían en tres casas, tres bodegas y un lagar con sus cubas y otros efectos de vinatería en Machacón, además de 113 aranzadas y 312 estadales de viñas en ese término y en los de Calvarrasa de Abajo, Francos y Villagonzalo, todos en tierra de la Armuña y bastante próximos a Salamanca. La escritura de venta se llevó a cabo el 31 de enero de 1778 y su precio, una vez redimidos varios censos con que estaba hipotecada esta hacienda y la habían mantenido indivisa, se fijó en la elevada cantidad de 140.410 reales, de los que se rebajaron 8.200 reales por los tres aniversarios perpetuos de los que debería hacerse cargo

debajo del precio de compra. AHPSa, Protocolo 2885, ff. 6-7r.; Protocolo 3098, ff. 320-321 y Protocolo 5774, ff. 635 y ss.

${ }^{97}$ AHPSa, Protocolo 5871, ff. 176r.-177v. El arrendatario era Antonio Herrera y seguía siéndolo cuando se repartieron las tierras entre los herederos en 1793. el comprador así como de las labores realizadas en las viñas ese $a \tilde{n} 0^{98}$.

Una de las casas era de gran tamaño, e incluía corrales, pajares y otras oficinas, entre ellas un lagar con su viga, piedra, pilón y una bodega con cinco cubas de $16 \mathrm{y}$ 14 palmos, bien es verdad que "desbaratadas", y un cubetillo de cerezo. Estaba situada en el centro del pueblo, con fachada hacia el descampado que se extendía junto a la iglesia. Justo bajo este terreno había una extensa bodega subterránea, llamada "cañón de trasiego", que describía en su recorrido una escuadra con entradas de ladrillo en los dos extremos y huecos de ventilación, tal como todavía puede verse. Había en ella diecisiete cubas en buen estado y un canal para acarrear el mosto con ocho arcos de hierro ${ }^{99}$. Otra de las casas se conocía comúnmente como "de Barba" o "del agua", y tenía su correspondiente lagar con sus pertrechos y una bodega pequeña del mismo nombre con su sobrado, y en ella cinco cubas ${ }^{100}$. La tercera era una casita pequeña con una cortina a su espalda con una noria.

${ }^{98}$ Los tres aniversarios sumaban 82 reales anuales: dos de 25 reales cada uno en la iglesia de Machacón y el tercero de 32 en la de Calvarrasa. La distribución de viñas era la siguiente: 46 en el lugar de Calvarrasa de Abajo, que sumaban 46 aranzadas y 115 estadales; 11 en el término de Machacón que hacían 33 aranzadas y 357 estadales; 15 viñas situadas en Villagonzalo, que sumaban 17 aranzadas y 197 estadales y 12 viñas en Francos que sumaban 22 aranzadas y 43 estadales. En Villagonzalo compraron también una cortina cercada, inmediata a la iglesia, conocida como "sitio o solar de lagar". AHPSa, Protocolo 5768, ff. 67-82.

${ }^{99}$ En el Catastro de Ensenada se indica que la bodega tenía sesenta y cuatro varas de fondo y cuatro de frente. Cuando pertenecía a Nicolás Romero su renta se regulaba en 300 reales anuales (AHPSa, Catastro de Ensenada, libro 1358, f. 126v.). Los hijos de Quiñones la dividieron en dos al repartir sus bienes. Había en ella una cuba de siete palmos, otra de ocho, otra de nueve, ocho de diez, tres de doce y tres de catorce

${ }^{100}$ En este caso eran cubas de 6, 8, 10, 12 y 16 palmos. AHPSa, Protocolo 5774, ff. 635 y ss 
Apenas un mes después de adquirir estas propiedades, el 10 de marzo de 1778, García de Quiñones compró otras en Villagonzalo, destinadas también al cultivo de vides. En concreto una casa con varias oficinas, boil y bodega con ocho cubas, trece tinajas para vino, un arco de hierro, mesa para cargar pellejos, escalera y otros pertrechos de vinatería. Además, un pajar frente a la casa con un corral y un lagar provisto de viga, usillo, pilón, tablero y cuñas, dos lagaretas y caballeriza. Amplió al mismo tiempo sus tierras en este lugar y en el de Francos con varias viñas que sumaban en total casi doce aranzadas. El precio, incluidas las labores realizadas, ascendió esta vez a 11.500 reales de los que se rebajaron 1.066 reales de dos aniversarios y un foro perpetuo que debería pagar en adelante el comprador $^{101}$.

Jerónimo García de Quiñones se encargó de hacer los arreglos necesarios en las casas y bodegas de Machacón y, al igual que había hecho su anterior propietario, se contrató a un mayordomo o administrador para que estuviese al frente de la explotación. Andrés García de Quiñones se convirtió a partir de entonces en cosechero de vino, que abastecía a Salamanca de este artículo, entrando a formar parte del gremio de "herederos de viñas", que si bien no tuvieron la fuerza de otros lugares, tenderían igualmente a monopolizar el comercio del vino, excluyendo o limitanto la entrada de otros de mejor calidad hasta que no se hubiese consumido el elaborado en el término $^{102}$. Para desarrollar esta actividad, el 2

101 AHPSa, Protocolo 5768, ff. 67-82 y ff. 99-102. Estas propiedades pertenecían a don Lorenzo Pérez Blanco, procurador de las causas del número de Salamanca y su mujer doña Antonia Zaragoza Godínez y García, que las había heredado en dote de su padre don Agustín Zaragoza y Godínez en 1776.

${ }^{102}$ Esto es lo que sucedía en Valladolid. Al respecto, A. MARCos MARTín, España en los siglos XVI, XVII y XVIII, Madrid, 2000, p. 254. La producción salmantina de diciembre de 1778 Quiñones alquiló al hospital de Santa María la Blanca por 330 reales una bodega en la calle de San Justo provista de cubas en las que poder echar el vino destinado a la venta ${ }^{103}$. Para aumentar su producción parece que compraba también uva a otros propietarios, pues Juan Galache, beneficiado de Calvarrasa, le demandó por los 1.000 reales que al parecer le debía por este concepto. Asimismo, desde al menos 1780 se conservan varias escrituras de fianza, junto a las de otros "herederos de viñas", comprometiéndose a pagar al Ayuntamiento los arbitrios o tributos correspondientes al vino que traía de Machacón para su venta, que solía ser un mínimo de tres carros ${ }^{104}$. Por lo demás, se mostraba cuidadoso en pagar los distintos impuestos que gravaban estos bienes: los diezmos a las parroquias, la alcabala de Machacón, el de fiel medidor o el servicio ordinario, las cargas de los aniversarios que tenían algunas propiedades..., cuyos recibos tenía bien ordenados en un legajo junto con las rentas de casas y bodegas. Este hecho parece contradecir su condición de hidalgo, por la que debía estar excluido de este tipo de impuestos, sobre todo del servicio ordinario.

Todos estos bienes raíces fueron valorados por sus herederos en 200.000 reales aproximadamente. Debían de proporcionar

de vino, sin embargo, no era abundante y en opinión de Larruga los cosecheros no habían encontrado "el arte que es frequente en otros paises". E. LARRUGA, Memorias políticas y económicas sobre los frutos, comercio, fábricas y minas de España, Madrid, 1795, tomo XXXIV, p. 304.

103 Pagaría la renta en los tres plazos habituales de Pascua de Navidad, la de Flores y en San Juan de junio. AHPSa, Protocolo 5865, f. 178.

${ }^{104}$ Los fiadores solían ser Agustín, Lorenzo o Francisco Pérez, que se encargaban de la venta. AHPSa, Protocolo 5218, f. 639; Protocolo 5966, año 1780, f. 98; 1781, f. 35, 1782, f. 44; Protocolo 5221, 1783, f. 567 y Protocolo 5222, 1784, f. 923. En el momento de su muerte debía de impuestos 260 reales y 14 maravedíes por los tres carros vendidos en agosto de 1784 . 
a García de Quiñones unos ingresos anuales de unos 8.000 reales, que si bien están lejos de las rentas de la nobleza o de la gran burguesía agraria, le aseguraban una posición económica relativamente acomodada y le permitirían mantener un estilo de vida material superior a la media de los vecinos, que se reflejaba en la casa que habitaba y en su atuendo.

\section{UN ESTILO DE VIDA ACOMODADO: LA CASA}

Aunque Andrés García de Quiñones compró en 1778, como acabamos de ver, una buena casa en Machacón donde residía algunos días del año ${ }^{105}$, nunca tuvo una vivienda en propiedad en Salamanca. Al regresar de Portugal en 1736 se estableció sucesivamente en las parroquias de Sancti Spiritus, San Blas y finalmente, hacia 1745, en la de San Isidoro y San Pelayo, donde arrendó al Colegio de la Compañía una casa a sus espaldas, "a mano izquierda según se baja de la calle Serranos" al Colegio de los Verdes, lindando con éste y con la calleja cerrada inmediata a él. Tenía un alto sobre la planta baja y corral y pagaba por ella 220 reales al año ${ }^{106}$. Esta proximidad le facilitaría la dirección de la obra de la Compañía, de la que había sido nombrado maestro. Permaneció en esta casa hasta su marcha a Galicia y después debió de alquilarla su hijo Jerónimo. Con la extinción de los jesuitas, todas sus propiedades pasaron a integrar el real patrimonio y fueron

105 También su anterior propietario, don Nicolás Romero, vivía aquí a temporadas. El valor de los muebles, utensilios y ropa que había en esta casa era, sin embargo, bastante inferior al de los que tenían en Salamanca, y de muchos de ellos se dice que eran "viejos". Las otras casas adquiridas en Machacón y Villagonzalo las tenían alquiladas. ARCHVa, RE, caja 3598-5, ff. 22-23v. Sobre la estancia en Machacón hay referencia en, ARCHVa, RE, caja 3577-16.

106 Medía 20 varas de frente y 24 de fondo, sin el corral. AHPSa, Catastro de Ensenada, leg. 2047, f. 3410. vendidas en pública subasta. Cuando en noviembre de 1769 se procedió a subastar esta casa, la número veinte, aquél se encontraba de viaje y al volver -"para ebitar el dolor de salir del rincón donde me había criado y en que había experimentado buena salud"-, tuvo que aumentar la puja una sexta parte de lo ya ofrecido, quedándose con ella por 4.900 reales, si bien la Junta de Temporalidades no le otorgó la escritura de venta en ese momento ni le exigió el importe hasta decidir sobre un foro perpetuo que tenía de carga. A pesar de ello, Jerónimo García de Quiñones, considerándose propietario, procedió a socalzarla en toda la fachada de piedra tosca, construyó otras oficinas y prácticamente la reedificó de nueva planta, dado el mal estado en que se encontraba ${ }^{107}$.

Cuando Andrés García de Quiñones volvió de Asturias se avecindó de nuevo con su familia en su antigua parroquia de San Isidoro, buscando sin duda la cercanía y el apoyo de su hijo Jerónimo. Pero en 25 de junio de 1779 se trasladó a la feligresía de San Martín donde arrendó una casa junto al mesón de las Tablas, detrás del

\footnotetext{
-

107 Jerónimo llegó incluso a enajenar esta vivienda en favor de su hijo don Joaquín, para formar judicialmente con ella y otras propiedades la "congrua sinodal" necesaria para que se ordenase. Sin embargo, en agosto de 1787 don Vicente Antonio Pedraz, como administrador de las rentas y efectos de los regulares expulsos de la Compañía, le demandó ante el corregidor para que pagase los alquileres de la casa desde 1770 hasta entonces, pues aunque se dio por vendida, nunca se había efectuado la venta. Tras varias informaciones y pedimentos de ambas partes, el 24 de noviembre de 1788 el corregidor don Miguel José de Azanza dictó sentencia favorable a Jerónimo García de Quiñones, ordenando que se otorgase la correspondiente escritura y pagase el importe del remate, una vez rebajada la cantidad del foro. Don Vicente Pedraz recurrió ante la Chancillería, que confirmó la sentencia del corregidor, condenando al escribano Montero a pagar las costas del juicio, por ser el causante con su negligencia de todos los problemas. La venta se efectuó el 22 de junio de 1793. AHPSa, Protocolo 4296 (año 1794), f. 100-142. ARCHVa, RE, caja 3621/06.
} 
Peso, perteneciente al regidor don Julián Rascón, vizconde de Revilla ${ }^{108}$, y muy próxima a la bodega alquilada para guardar su vino. Además de estar más céntrica, debía de tener mayor amplitud lo que permitiría una clara especialización de los espacios y alojar con cierta holgura al matrimonio, su hija viuda con los dos nietos, el hijo soltero y al menos dos criados: Gracia Sánchez y un joven estudiante de la Universidad, Pedro García Robles, al que curiosamente se le da el apelativo de "don". También eran criados Agustín Pérez y José Bernardo Soria, aunque no nos consta que viviesen en la casa. Esto explica que la renta anual de la vivienda ascendiese a 750, más del triple de la que había ocupado antes de marcharse a Galicia y buen reflejo de la fortuna adquirida. Prueba de su tamaño es que apenas medio año después de la muerte de Andrés García de Quiñones, y todavía con todos sus muebles y enseres guardados en la sala principal, se alojó en la casa una bandera de soldados $^{109}$.

Desconocemos cual era su distribución, ya que en el momento de hacer el inventario todos los bienes se encontraban agruparon en una o dos estancias, pero sabemos que la escalera principal comunicaba con la sala, a la que se abrían dos alcobas. Esta sala debía de ser la habitación más representativa y en ella encontramos los muebles más valiosos que había ido adqui-

108 AHPSa, Protocolo 5965, fol 5 r. y v.

${ }^{109}$ Lo denuncian varios hijos el 1 de agosto de 1785 , por los robos y el deterioro a que estaban expuestos los bienes y muebles por este motivo (ARCHVa, RE, caja 3598-05, f.29r.). En julio estuvo acuartelado en Salamanca el regimiento de caballería del Rey, que ocupó fundamentalmente los mesones, pero debieron recurrir también a algunas casas próximas para alojar a los soldados. AMS, Libro de Acuerdos de 1785, consistorio de 3 de agosto. M. N. RupÉREZ ALMAJANO, «La Guerra de la Independencia y su incidencia en el patrimonio arquitectónico y urbanístico salmantino", Salamanca. Revista de Estudios. núm. 40, 1998, pp. 258260. riendo el matrimonio ${ }^{110}$. Contenía una mesa de pino con su cajón, doce taburetes de baqueta de moscovia y doce sillas de nogal forradas de gamuza y madera por abajo; también eran de nogal un bufete con barrotes de hierro, una escribanía-papelera inglesa chapada ${ }^{111}$ con nueve cajones, en la que Quiñones guardaba todas las escrituras y papeles importantes, y otro escritorio de tapa de nogal con su cajón y mesa de pino chapada, en el que había cosas de lo más dispares, desde una caja con cuchillos de mangos de plata a las pelucas del arquitecto, unos botones de puño, peinadores o camisas, posiblemente todo de su uso. La sala se enriquecía con otros objetos valiosos, como un reloj con su caja barnizada de colores y dorado, dos espejos grandes con marco dorado, siguiendo la moda francesa, y seis cornucopias con espejo y alambres de bronce que servirían para alumbrar la estancia. En las paredes colgaban dos únicos cuadros de tema religioso: una lámina de la Magdalena en cristal con marco y un lienzo con una efigie de Nuestra Señora con moldura y tarjeta dorada con los costados guarnecidos de "palón de oro"; había también una efigie de un Cristo crucificado con peana de madera dorada, posible sobre una mesa o bufete. El suelo se cubría con varios ruedos y el balcón -con puertas de 22 cristales- se cerraba con una cortina de damasco carmesí de lana y sus borlas de estameña con su correspondiente cenefa. Recorría la sala una moldura de media caña tallada y dorada con una tarjeta y un friso de charol.

Andrés García de Quiñones guardaba sus pertenencias más personales en un

${ }^{110}$ Los datos que ofrecemos a continuación proceden del inventario de bienes que aparece inserto en la ejecutoria del pleito litigado entre los hermanos. ARCHVa, RE, 3598-5, ff. 12 y ss.

111 Se suele dar el nombre de "papelera" a un mueble o a un escritorio que presenta filas de cajones en el frente. 
baúl forrado de cuero y con cerradura, pero también encontramos otras prendas de vestir suyas, junto con otros enseres dispares y ropa de casa -sábanas, mantelerías, servilletas, etc. - distribuidos entre un arcacajón de pino descerrajada, un baúl forrado en lienzo pintado (que quizá perteneció a su esposa) y otro baúl con cerradura, que pudieron estar en las alcobas que daban a la sala principal. En una de ellas tenía su cama García de Quiñones, un buen catre de nogal con colgaduras de lona cuya valoración ascendió a 280 reales, con dos buenos colchones, uno de terliz y otro de lienzo, ambos con su lana. Allí había además dos sillas de brazos de nogal con baqueta negra, una mesita pequeña de pino, tres arquetas de madera de cedro con barrotes de hierro y su cerradura y una frasquera provista de cerradura con ocho frasquitos de cristal, esto último sin duda destinado a su aseo.

En la casa encontramos otros baúles donde guardaban sus efectos $M^{\mathrm{a}}$ Eugenia, Andrés y los nietos. La primera tenía dos, uno de ellos de baqueta de moscovia por fuera y forrado de seda por dentro, además de un arca. Andrés otros dos, uno con cerradura forrado de anjeo y tapa de jabalí y otro pequeño con cerradura forrado en lienzo pintado. La ropa de los nietos se guardaba en otros dos baúles, uno forrado en lienzo pintado y otro sin forro, y había otro baúl que sólo contenía papeles de dibujo y otras "chucherías" de ellos. M $\mathrm{M}^{\mathrm{a}}$ Eugenia dormía en un catre de nogal con colgaduras de lana y tres colchones, todo ello con su correspondiente ropa de cama: sábanas, mantas, colchas, sobrecamas y dos almohadas, que quizá con anterioridad había ocupado su madre. No obstante, en el inventario se contabilizan como mínimo otras seis camas más, en este caso de cordeles, y al menos dos catres, provistos asimismo de uno o dos colchones, almohadas, sábanas, mantas, etc., de calidades diversas, que sobrarían para cubrir las necesidades de todos los inquilinos de la casa.
En una habitación se habían acumulado otra serie de muebles y objetos cuya distribución se nos escapa, como un reloj de madera, un bufete de nogal, una caja de brasero también de nogal, una docena de sillas grandes y diez pequeñas, una mampara, un biombo de cinco piezas, una efigie de la Magdalena y otra, de más valor, de Nuestra Señora enmarcadas, además de otras seis estampas de papel y nada menos que cincuenta y siete cuadros con sus vidrios y marcos dorados de los misterios de Nuestra Señora, a cuatro reales cada uno. La vajilla de cierta calidad se guardaba en un buen aparador o alacena de madera de pino. Allí había unas aceiteras de cristal con agarradores de estaño, vasos de cristal pequeños, y una proporción de loza fina -dos docenas de platos, cinco medias fuentes y una jarra con su cuenco, platillos y tazas todo de cerámica de Alcora-, botellas para vino, tablas que servían de base, vasos ordinarios de barro fino y basto, dos saleros de peltre, cestas, manteles, paños de cocina, etc. Recientemente parece que habían adquirido tres docenas de platos de peltre, fabricados en Inglaterra, que estaban nuevos. En la cocina y despensa hubo en su día una mesa con dos cajones, otra de pino con su cajón y otra más pequeña sin cajón, además de seis taburetes de pino, un brasero, nueve tinajas grandes con tapadera y otra pequeña. Tenían también tres tajos de picar, uno de ellos grande, dos planchas de hierro, algún farol, loza ordinaria, un almirez, un calentador, una tartera pequeña de cobre, cazos, sartenes, una chocolatera de cobre, una olla de cobre para la lumbre y otros muchos efectos propios de una casa, que creemos innecesario enumerar dado que lo señalado ya resulta suficientemente ilustrativo.

Una valoración aparte merecieron los objetos de plata, considerados como alhajas, y cuya posesión constituía ya un signo de distinción, como parece querer resaltar Andrés García de Quiñones al mencionar- 
los en uno de sus testamentos. No eran muy numerosos y su precio dependía no tanto del diseño como de la cantidad de plata. Consistían en el momento de morir el arquitecto en docena y media de cubiertos: cucharas y tenedores de la misma hechura y cuchillos, un cucharón de filetes y un trinchete con el mango de plata, como en el caso de los cuchillos, dos salseras pequeñas con tapadera de concha a la inglesa, otras dos salseras en forma de lancha con dos asas y pie, una salvilla grande con moldura levantada al canto y cuatro pies y otra mediana con moldura soldada con tres garras por pies, un azafate grande de forma ovalada decorado con trofeos de guerra en medio y otro pequeño con un paisaje de granja.

\section{EL TRAJE COMO SIGNO VISIBLE DEL ESTATUS SOCIAL}

$\mathrm{Al}$ igual que en la casa, las ganancias adquiridas tuvieron su reflejo en el traje y la apariencia externa, que ordinariamente denotaban el estatus social de los individuos. El vestuario de Andrés García de Quiñones, bastante bien surtido, y el de su hijo Andrés que convivía con él, nos transmite una imagen si no de gran lujo y ostentación, sí de personas acomodadas y con cierta distinción social. Sus pertenencias incluían varios "vestidos", presumiblemente de casaca, chupa y calzones, según la moda masculina de la segunda mitad del siglo XVIII impuesta por la corte francesa, que resulta también patente en algunos de sus tonos y tejidos, ajenos por completo al vestir popular, y en la importancia de botones, jarreteras y hebillas como elementos decorativos ${ }^{112}$. En concreto, Quiñones po-

112 Sobre las prendas más frecuentes en esta época, A. LEIRA SÁNCHEZ, «El vestido y la moda en tiempos de Goya», Textil e indumentaria: materias, técnicas y evolución, Madrid, 2003. seía dos vestidos de "carro de oro"113, uno azul celeste forrado en tafetán verde con jarreteras y botones de hilo de plata fino y otro tornasolado con el mismo adorno pero a mitad de precio, quizá por estar ya muy usado; otros tres vestidos de paño Sedán, un paño fino de gran calidad de uso frecuente en Galicia, donde quizá los adquirió: uno morado forrado en sarga verde, otro azul celeste forrado en sarga encarnada y otro "color de carmelita" con forro del mismo color, todos con botón y jarreteras de hilo de oro, además de otro vestido de paño negro forrado de sarga.

Complemento de estos trajes serían tres camisas de muselina y otras dos más, todas "con vueltas", y varios pares de medias negras: de seda, de estambre y de lana. $\mathrm{Su}$ ajuar incluía otras prendas, como un calzón de terciopelo negro y otro más modesto, una chupa de pana negra forrada de sempiterna blanca, varios paños de manos de lino, de encajes, ... -, ocho pañuelos de colores, varias batas "con cuartos de chu$\mathrm{pa}^{\prime \prime}$-una de china, otra de indiana y otra de bayetón forrada en color carmesí y blanco-, a modo de vestiduras holgadas propias de personas pudientes que debía usar cuando trabajaba en su casa, y otras prendas interiores: al menos tres camisas y tres pares de calzones de crea ${ }^{114}$ En su inventario aparecen también algunas prendas de abrigo: en lugar de capa, un "sortú" a modo de capote o sobretodo de barragán aplomado de Inglaterra y un airoso casacón drapeado con beca de lana. Para su aseo tenía un paño de afeitar de true ${ }^{115}$ con encaje y una caja de baño acharolada. Usaba sombrero de tres

\footnotetext{
113 Se conocía como "carro de oro" una tela tornasolada, muy fina, de lana. Diccionario de la Lengua Española. Madrid, 1992.

114 Idídem. Crea era un lienzo entrefino que se usaba mucho para sábanas, camisas, forros, etc.

115 Era un lienzo delgado y blanco. Diccionario de la Lengua Española. Madrid, 1992.
} 
$\operatorname{picos}^{116} \mathrm{y}$, en ocasiones, debía de realzar su porte externo con una peluca, pues tenía dos ejemplares de cada uno. Dados sus frecuentes viajes y la inseguridad de los caminos no es de extrañar encontrar también entre sus pertenencias un par de pistolas portuguesas de Arzón y otra de cinto.

El ajuar de su hijo incluía asimismo una variedad de trajes tan ricos con los del padre, pero en los que parece advertirse la evolución que se produce en la moda masculina con tendencia a chupas cada vez más cortas. Poseía un vestido de casaca y media chupa de pelo de camello en color plata con botones de hilo de plata vieja; una casaca y chupa de "medio carro" con forro carmesí y botón de hilo de plata; varios vestidos enteros de paño: uno verde mar forrado de raso liso con botón y jarreteras de hilo de oro y galón de lo mismo a la chupa, otro de color cobre con forro verde con botón de metal y galón de oro a la chupa y otro drapeado en plata con forro del mismo color y botones de metal, además de dos vestidos cortos de tela blanca forrados en crea. En sus baúles había otras prendas sueltas, como una chupa y cuartos de chaleco de pana con galón de oro fino y botones de metal, unos "cuartos de chupa" glasé117 de plata, otra carmesí de color ante con bordadura de oro en el canto, y una más junto con calzones de raso liso carmesí con jarreteras y botón de hilo de oro, además de tres pares de chalecos con cuartos de seda negros, unos calzones viejos y una montera (sombrero de tres picos) de terciopelo negro, una capa drapeada color aceituna con dos becas, una de terciopelo negro y otra trenzada de oro fino, y otra capa de verano "de medio carro" con becas de tafetán carmesí y seda. En su atuendo no podían faltar las medias, de las que tenía nada menos que veinte pares

\footnotetext{
116 Tenía dos y una montera de camino negra.

117 Tafetán de mucho brillo
}

viejos, de seda, hilo y estambre, unas blancas y otras negras, las camisas con sus vueltas -nueve en total y todas usadas-, ni los corbatines -siete también viejos-, a los que había que sumar un par de guantes blancos, una faja de seda vieja encarnada y negra, dos mudas de ropa de cama, siete pares de calzados y un par de botines de paño negro $^{118}$. Esta cantidad de camisas, medias o corbatines resulta un tanto sospechosa y bien pudiera haber tomado algunas de las que pertenecían a su padre.

También resulta extraño que sólo entre sus posesiones se citen otros objetos y accesorios que tenían un gran protagonismo en la indumentaria del XVIII, tanto de hombres como de mujeres, como es el caso de las hebillas, que adquieren la categoría de joya de moda ${ }^{119}$. De hecho en el inventario fueron consideradas entre las alhajas. No obstante, varias cajas de hebillas grandes labradas para zapatos y de hebillas de filetes con charnelas de hierro que tasó el contraste debían de ser de Quiñones, al igual que un par de botones de puño de plata y concha. Su hijo reclamaba exclusivamente como suyos dos juegos de hebillas de zapatos y jarreteras de plata, uno de ellos guarnecido con piedras de Francia ${ }^{120}$,

118 Andrés García de Quiñones anotó con detalle lo que le dio a su hijo Andrés entre 1771 y 1777, y ahí figuran varias partidas destinadas a ropa, como los 565 reales y medio que importó un vestido blanco de paño, los calzones de pana y medias de seda que compró en diciembre de 1771, los 120 reales de dos varas de terciopelo negro que dio "a Pepa" para una casaca en noviembre de 1773, los 66 que pagó a una costurera "de echura de camisas y la tela de las vueltas" o los 19 que dio al sastre por hacer unos calzones, en marzo de 1774. ARCHVa, RE, caja 3598-5, p. 33v.

${ }^{119}$ M. A. Herradón FigueroA, «Las hebillas, joyas olvidadas», en Indumenta: Revista del Museo del Traje, núm. 1 (2008) pp. 104-125.

${ }^{120}$ Ibidem. Con este nombre se conocía el estrás, un tipo de vidrio inventado en 1734 por George Fréderic Strass dotado de un brillo singular gracias a las facetas talladas, pero de coste moderado. Por sus propiedades 
una combinación que tuvo gran éxito. Además de este tipo de hebillas que eran las más frecuentes, Andrés tenía dos más, también de plata, una de corbatín y otra en un cinturón de terciopelo negro con galón rojo. Aparte de dos pistolas de Arzón, entre sus posesiones aparecen otros instrumentos que prácticamente habían perdido la función defensiva original y se habían convertido en accesorio del traje francés, marcando por su carácter suntuario un cierto estatus social. Es el caso de un espadín, con puño y abrazadera de plata decorado con trofeos de guerra y un "cutó" o sable con estrella de plata en la empuñadura, que llevaba colgado de un "biricú" (bridecú o tahalí) de seda azul cruzado sobre el pecho. Al parecer Andrés García de Quiñones también tuvo un espadón de plata, pero se lo había dado a su hijo Jerónimo. Otro signo de riqueza era el reloj de faltriquera o bolsillo; su yerno había visto uno de plata de poco valor colgado en la alcoba de su suegro, que según él mismo le dijo, se lo había dado a su hijo Andrés.

Además de las hebillas, charreteras o el espadín de que hemos hablado, había en la casa algunas otras joyas o adornos, parte de los cuales tanto $\mathrm{M}^{\mathrm{a}}$ Eugenia como su hermano Andrés, intentaron reclamar sin éxito como de su pertenencia. Las más destacadas parece que eran un collar de aljófar de cinco hilos, unos pendientes de filigrana de oro de botón, lazo y almendra guarnecidos de aljófar menudo, una crucecita de oro con botón de plata y en él chispitas de diamantes y un topacio y, finalmente, otro aderezo de oro grande compuesto de lazo con sus ramos y cruz, todo calado, con botón de una pieza y una almendra, que sólo en su valor intrínseco, sin incluir el mucho trabajo que llevaba, ascendía a 1.300 reales a juicio del contraste de la ciudad, don En-

se convirtió en un sustituto del diamante y se aplicó en todo tipo de joyas falsas. rique de Silva, encargado de su tasación. Todo esto debió de pertenecer a doña Ana de Otero. Había otros objetos de menos valor, como un adorno pequeño de cruz y pendientes, cuatro botones de puño y dos pulseras, todos guarnecidos con piedras de Francia, dos medallas, una de Nuestra Señora de Fuensanta y otra del Pilar, dos rosarios pequeños engarzados en plata y unas medallas, un santo Cristo pequeño y una cruz de ánima, hebillas de mujer de piedras de Francia, un cuadro pequeño cincelado y alguna otra menudencia. No es que fuesen grandes alhajas, pero desde luego no estaban al alcance de todos los bolsillos y su valor, junto con la plata del menaje señalada más arriba casi llegaba a 10.000 reales, lo que para la época es considerable. Baste recordar que era el doble de lo que le costó a Jerónimo la casa compró.

\section{PERSONALIDAD Y BIBLIOTECA DE ANDRÉS GARCÍA DE QUIÑONES}

La variada documentación disponible ofrece una imagen de la personalidad de Andrés García de Quiñones de la que cabría destacar alguno de sus rasgos más notorios, en parte ya apuntados a lo largo de este estudio.

Debió de tener un temperamento sereno y ecuánime, "siempre de genio apacible"121. En la información secreta preceptiva para ingresar en la Orden Tercera del Carmen, el maestro de obras Félix Vaquero, que posiblemente le había tratado por motivos laborales, le definía como una "persona de buena vida y costumbres", al igual que su mujer ${ }^{122}$. Parece ciertamente que era

${ }^{121}$ Es lo que se afirma expresamente en la declaración de 12 de noviembre de 1784, y así debían reconocerlo todos los que le trataron. AHPSa, Protocolo 5871, f. 298.

122 Archivo Carmelitas Calzados, Libro de solicitudes de ingreso de 1732-47 (2), 19 de febrero de 1749. 
un hombre devoto y de profundas convicciones religiosas, como lo demuestra no sólo su pertenencia a varias cofradías -la del Santísimo de las parroquias de San Blas y de San Isidoro, de la que fue mayordomo al menos en dos ocasiones ${ }^{123}$, la de Ánimas de la parroquia de San Julián, la de Nuestra Señora de San Millán, la de Nuestra Señora de la Caridad de San Bartolomé y la de San Juan de los canteros situada en el convento de San Francisco, sino fundamentalmente su ingreso en esa Orden Tercera. La sinceridad de sus creencias se puso también de manifiesto en el hecho de que, cuando se vio con medios para ello, no sólo trató de asegurarse un futuro material mediante la adquisición de tierras, sino que procuró asimismo obtener un rendimiento espiritual de su dinero, destinando una cantidad a la fundación de dos misas perpetuas, "para exaltar el culto de Dios Nuestro Señor y de su Santísima Madre" y en beneficio de sus almas y las de sus padres, lo que hizo realidad en 26 de noviembre de $1777^{124}$, unos años antes de su muerte.

Andrés García de Quiñones debió de ser un esposo y padre ejemplar, unido estrechamente a su mujer y volcado en el atento cuidado de las necesidades de sus hijos y nietos, a los que sin duda quería de modo entrañable, pues entre sus papeles conservaba tres legajos con las cartas que le habían escrito Jerónimo, Antonio Cándido y Francisco, en distintos años ${ }^{125}$. Era, por otro lado, un hombre con una cierta cultura, como atestiguan los libros que todavía conservaba a su muerte, de los que hablaremos más adelante. Además de leer, escribía de manera cuidada y con soltura y ha-

\section{-}

${ }^{123}$ Figura como tal en las cuentas de 1754 en 1755 y 1758 en 1759. ADS, 417/26, ff. 59v.- 66r y 83r.-f. 86.

124 AHPSa, Protocolo 3710, ff. 298-302 y 303-310v.

${ }^{125}$ ARCHVa, RE, caja 3598-5, f. 19. bía procurado inculcar una educación básica a todos los miembros de su familia, incluidas sus hijas.

La formación recibida pudo también influir en la minuciosidad y el riguroso orden con que llevaba sus asuntos y negocios, especialmente lo relacionado con el manejo de las cuentas, cuya documentación guardaba en legajos perfectamente identificados. Curiosamente, entre esos papeles no había ninguno relacionado con trazas arquitectónicas, obras o informes en los que hubiese intervenido como arquitecto $o$ maestro de obras, quizá porque los había cedido a sus hijos del mismo oficio, o simplemente porque los había destruido al haber perdido su vigencia. Guardaba, sin embargo, todo lo concerniente a las cuestiones que habían acaparado su atención en los últimos doce años: los libros y papeles relativos al abasto de maderas, dado que podían ser necesarios para recuperar lo que todavía le adeudaba la Real Hacienda, los correspondientes al pleito con Omaña, todo lo relativo a la recuperación del vínculo de Villafranca, que no acababa de conseguirse pese a la sentencia de la Chancillería a su favor, así como la abundante correspondencia con Jerónimo Hijosa y la cruzada con sus agentes o representantes en Avilés, el Ferrol o Madrid, dedicada en parte al seguimiento de los pleitos.

Asimismo conservaba con cuidado no sólo los recibos de los pagos que había efectuado por distintos conceptos, sino también los de las personas que tenían alguna deuda contra él, pues además de adelantar dinero a sus hijos, parece que con cierta frecuencia prestó distintas cantidades, algunas de las cuales seguían pendientes de cobro cuando murió. Al menos en un caso el préstamo fue acompañado del empeño de objetos con los que pudiera resarcirse Andrés García de Quiñones en el caso de no producirse la devolución, como sucedió con el baúl con distintas "alhajas" - 
varias colchas, camisas de hombre, sábanas, un brial, mantos, etc.- que le dejó don José García Cano a cambio de 800 reales. Desconocemos si cobraba algún tipo de interés por estos préstamos, pero sus herederos consideraron algunos incobrables, como los 2.000 reales que había dado a doña Juana Valdés, vecina de Avilés, según constaba por un vale de 2 de julio de 1777 en poder de don Luis de Sama, agente suyo en ese lugar ${ }^{126}$. Lo que claramente tuvo un carácter lucrativo fueron los 16.000 reales que entregó a censo a la comunidad de carmelitas calzados el 2 de agosto de 1777, al poco tiempo de llegar a Salamanca y antes de comenzar a adquirir tierras. Este censo, al respecto del $2,5 \%$ le reportaba una renta anual de 400 reales, aunque el 23 de diciembre de 1783 dio poder a su yerno Sopuerta para que lo traspasase al convento de la Madre de Dios ${ }^{127}$ ante la necesidad de disponer de dinero líquido para diversos gastos.

Quiñones se enorgullecía del "honor i estimación" con que había desempeñado su encargo de asentista ${ }^{128}$, pero también es verdad que tanto en este trabajo como a lo largo de su trayectoria profesional se vio involucrado en algunos pleitos que cuestionaron el buen cumplimiento de sus compromisos, aunque no tuvieron la gra-

${ }^{126}$ Había otros vales de distintas cantidades entregadas por Andrés García de Quiñones: 200 reales a Alonso Escudero Fraile, 1.059 reales y 26 maravedís según una cuenta de Vicente Sánchez Zúñiga en Hervás; 300 reales a Agustín Pérez Monroy y Tomás Monroy, de los que ya habían abonado 200 a tenor de una nota añadida, también Juan García y Domingo Gómez, vecinos de Machacón habían pagado parte de los 190 reales que le debían. Había otros deudores de Machacón, Villagonzalo, el Acebo, etc. Y entre ellos estaba también su amigo Melchor Pérez de Torres, al que prestó más de 3.000 reales. ARCHVa, RE, caja 3598-5, f. 18.

127 AHPSa, Protocolo 5215, ff. 531-546 y ARCHVa, RE, caja 3598-5, f. 45.

128 AHPSa, Protocolo 5768, f. 673. vedad ni el peso suficiente para empañar su buen nombre ${ }^{129}$. De lo que no cabe duda es de que fue un hombre emprendedor, dispuesto a cambiar de residencia si así lo requerían las circunstancias y a afrontar nuevos retos profesionales sin detenerse ante obstáculos, en algún caso tan objetivos como la edad. Según su hijo Jerónimo poseía "un entendimiento claro y perspicaz"130, que conservó hasta el final aunque la enfermedad le mantuviese prácticamente inmóvil, y por otro lado las obras que realizó demuestran que no le faltó talento, por lo que fue capaz de ganarse la confianza de personas influyentes.

No obstante, a pesar de la iniciativa que manifiesta para los negocios, su mentalidad parece responder todavía a esquemas tradicionales, no sólo porque le preocupase recuperar un vínculo o mayorazgo de Villafranca al que tenía derecho por herencia materna, sino especialmente por la inversión de las ganancias obtenidas con la especulación en las compra de inmuebles y tierras, tal como ha quedado señalado más arriba. Eran medios habituales para quien aspiraba a un ascenso social, pero más que alterar la sociedad estamental no hacían más que reforzarla ${ }^{131}$.

Por otro lado, en sus relaciones y amistades más cercanas, al margen de las obligadas por el trabajo, parece como si hubiese procurado un cierto distanciamiento del ámbito puramente artesanal y cultivado el trato con personas de un nivel social o intelectual medio o alto. Es significa-

\footnotetext{
${ }^{129}$ Además del pleito con Omaña, al que ya hemos aludido, en los primeros años de su actividad como arquitecto fue denunciado por incumplimiento de su obligación en la construcción del polvorín de Ciudad Rodrigo, llegando también el tema al Consejo de Guerra. Cf. al respecto, $M^{a}$ N. RUPÉREZ ALMAJANO, «Los inicios profesionales..., art. cit.

130 ARCHVa, RE, caja 3598-5, f. 35.

131 A. MARCOS MARTíN, art. cit. pp. 19-47.
} 
tivo al respecto que además de su hijo Francisco, todos sus nietos varones realizasen estudios universitarios, y las hijas y nietas contrajesen matrimonio con miembros de profesiones liberales, bien es verdad que no siempre hombres con fortuna. Él mismo debió de fomentar su educación y formación intelectual a través de la lectura.

La biblioteca de Andrés García de Quiñones en el momento de morir era escasa. Contenía poco más de veinte títulos en unos cincuenta tomos que fueron valorados en 248 reales. Los guardaba en la escribanía papelera, junto a todos los documentos importantes. No obstante, estos libros no eran todos los que tuvo, ni los que había tenido ocasión de manejar en algún momento. Hay constancia de que en 1750, en la almoneda de los bienes de Alonso de la Fuente, obrero menor de la catedral salmantina, adquirió una plomada y cuatro libros por 64 reales y, aunque no se indican sus títulos, en su inventario no aparecen ya ninguno de los doce que tenía este maestro. Eran éstos un libro de Sebastiano Serlio posiblemente los libros III y IV traducidos por Villalpando-, dos libros de la "Regla de los cinco órdenes de arquitectura" de Vignola, los dos tomos del "Arte y Uso de Architectura" de fray Lorenzo de San Nicolás, dos libros de Pietro Cataneo "Senesse" (uno de ellos de arquitectura militar), otro de Arfe -posiblemente "De varia conmensuración para la esculptura y architectura"-, el "Breve tratado de todo género de bóvedas" de Juan de Torija y una "Descripción del Escorial" que debía de ser la tercera parte de la "Historia de la Orden de San Jerónimo" de Fray José de Sigüenza, además de un libro de dibujos ${ }^{132}$.

132 AHPSa, Protocolo 4572, f. 132v. Mª N. RUPÉREZ ALMAJANO, «Bibliotecas de artistas salmantinos en el siglo XVIII», Los Clasicismos en el Arte Español. Actas del X Congreso Nacional del C.E.H.A. Madrid, U.N.E.D., 1994, pp. 516-518
En 1763 fue encargado de tasar los libros de Francisco Álvarez, un maestro de obras con el que debía de unirle cierta amistad. Este poseía algunos tratados clásicos de arquitectura -los libros III y IV de Serlio, "Los cuatro libros de arquitectura" de Andrea Palladio y un Vignola-, otros de orientación eminentemente práctica y tradicional, como el ya citado de fray Lorenzo de San Nicolás o las Ordenanzas de Torija, y varios libros de aritmétrica y geometría relacionados con la construcción, como el "Arte de medir tierras" de Andrés Dávila Heredia, varios tomos de Pérez de Moya (la "Aritmética práctica y especulativa" y el "Tratado de matemáticas") y la aritmética de Bartolomé Ferrer ${ }^{133}$, además de cuatro libros de dibujos, trazas y "mapas", uno de ellos con trazas de iglesias de Roma que Quiñones anota como de "Alberto Paulo"134. No cabe duda de que si Andrés García de Quiñones fue elegido para tasar estos libros es porque los conocía bien, y posiblemente más de uno los tuviese en su biblioteca. Lo más probable es que al llegar a una edad, e impedido como estaba, hubiese distribuido entre sus hijos arquitectos los libros e instrumentos que les podían ser útiles, reservándose tan sólo aquellos por los que tenía mayor aprecio.

Lo cierto es que muy pocos de los libros que había en su casa al morir estaban directamente relacionados con su profesión. Lo más destacado eran los nueve tomos del "Compendio matemático" de Vicente Tosca (Valencia, Imprenta de Antonio Bordazar, 1707-1715), que algunos historiadores consideran el tratado español de arquitectura más importante publicado en el siglo

\footnotetext{
133 Cf. M.V. SANZ, «El tratado de Arquitectura de Bartolomé Ferrer (1719)», en R.I.E. vol. XXXVI, núm. 142 (1978), pp. 111-129

134 Ma N. RUPÉREZ ALMAJANO, «Bibliotecas de...», art. cit. p. 518.
} 
XVIII ${ }^{135}$. Es probable que lo adquiriese en una fecha temprana, pues no hay que olvidar que su autor era miembro la Congregación del Oratorio de San Felipe Neri y Andrés García de Quiñones había sido el arquitecto del convento de esta institución en Viseu. La valoración de esta obra en tan sólo 60 reales, es muy inferior a los 90 y 160 que recibió en los inventarios de Juan de Sagarbinaga y Lesmes Gabilán ${ }^{136}$. Destacaban también por su alto precio - 30 realesseis tomos de "física experimental" que al no tener referencia de autor resultan difíciles de identificar, al igual que otros tres tomos en francés del "Arte Guerra". Este último debía de ser un tratado de arquitectura militar, lo que no resulta extraño dada la frecuente relación que mantuvo Quiñones con ingenieros militares a lo largo de su actividad profesional. Tenía otro libro de "geometría" de "Juan Jorbet", que quizá conservó por el hecho de estar escrito también en francés, una lengua de la que pudo tener algún conocimiento en contacto con los ingenieros franceses con los que se relacionó por su trabajo.

Junto a estos libros se podrían poner otros dos de escaso valor pero cuyos autores habían sido profesores de matemáticas de la Universidad de Salamanca, uno de ellos era el "arte de contar", que interpretamos como el del "Contador" Antonio Rodríguez, profesor de aritmética ${ }^{137}$; el otro

${ }^{135}$ F. J. LEON TELLO, «Introducción a la teoría de la Arquitectura de Tosca (1651-1725)», en R.I.E., vol. XXXV, núm. 140 (1977), pp. 287-298, y «La teoría arquitectónica de Tomás Vicente Tosca: montea y órdenes arquitectónicos», R.I. E., vol. XXXVI, núm. 144 (1978), pp. 289-323.

${ }^{136}$ E. AzOFRa Agustín, Ob. cit. p. 72 y AHPSa, Protocolo 3122, ff. 306 y ss.

${ }^{137}$ Arte subtilissima practica y teorica para poder contar guarismo de repente; por lo qual se haran con mucha facilidad todas las reglas, y reduciones de monedas, pesos y medidas, censos, rentas, pechos, alcavalas, y duanas, à tanto por ciento, que se vsan en Castilla, y otros Reynos. Madrid, es el libro de la "Vida" (Vida, ascendencia, nacimiento, crianza y aventuras de el doctor...) del célebre Diego de Torres y Villarroel, catedrático de Prima de Matemáticas, con el que Quiñones tendría ocasión de hablar más de una vez, aunque sólo fuera por haber sido encargado por el Estudio de lo relativo a la construcción de la casa que tenía en la Plaza Mayor ${ }^{138}$.

El libro reseñado como "secretos de agricultura" era posiblemente el del "Prior" Miguel Agustí, Libro de los secretos de agricultura, casa de campo y pastoril, publicado por primera vez en 1617 y del que se hicieron varias ediciones. Su posesión estaría bien justificada desde el momento en que Quiñones se había convertido en propietario agrario. No obstante era una obra muy difundida, que también estaba en la biblioteca de Simón Gabilán Tomé y luego en la de su hijo Lesmes ${ }^{139}$.

Aparte de varios libros viejos de gramática, el resto de los que conservaba eran obras de carácter literario, histórico o religioso, que utilizaría como lectura de entretenimiento o de formación religiosa, que era lo que en estos últimos años de su vida podía constituir su principal inquietud. Son títulos selectos, que no resultan tan habituales en las bibliotecas de arquitectos, pero también hay que tener en cuenta en este caso la influencia que pudieron ejercer en él sus amistades, los eclesiásticos y profesores de la Universidad con los que solía tener trato.

Así nos encontramos "la Historia de don Quijote", una de tantas ediciones que se hicieron de la obra de Cervantes, en este

Imprenta de Don Pedro Joseph Alonso de Padilla, 1728.

138 A. Rodríguez G. De Ceballos, La Plaza Mayor de Salamanca, Salamanca, 1991, pp. 144-145.

${ }^{139}$ Ma N. RuPÉREZ ALMAJANO, «Bibliotecas de...», art. cit., p. 521. 
caso encuadernada en cuatro tomos en pasta que vendrían a costar 32 reales.

Una "Historia del conde de Sague", en dos tomos en pasta y 10 reales, que quizá pudiera corresponder a la novela picaresca el dramaturgo y novelista francés André René Le Sage, traducida al castellano por el padre Isla como Historia de Gil Blas de Santillana.

Otros seis tomos de la "Historia Pontifical", que debieran corresponder a la obra de Gonzalo de Illescas, Historia Pontifical y Cathólica, en la cual se contienen la vida y hechos notables de todos los Summos Pontífices Romanos... (Primera parte, Dueñas, 1565), ampliada en varias ocasiones hasta completar los seis tomos por Luis de Babia, fray Marcos de Guadalajara y Juan Baños.

Dos tomos en octavo de la "Historia de España" del padre José de Isla, en 6 reales, que eran la traducción que hizo este autor del Compendio de Historia de España del padre Dúchense (Amberes, Hermanos Cramer, 1752).

Otros dos tomos en cuarto correspondían a la Clave historial, con que se abre la puerta a la historia eclesiastica, y politica,... (Madrid, 1743), del padre Enrique Flórez. A juzgar por el título también debía tener un carácter histórico o afín el libro reseñado como "Historia de las religiones eclesiásticas y militares". Dentro de este apartado podrían quizá incluirse otros títulos cuyo conocimiento se nos escapa, como los cuatro libros de "Reflexiones a favor de la casa de Lubiten", uno de "Derechos del Rey" y otro "Estado político"140.

${ }^{140}$ Con el título Estado politico de la Europa encontramos la obra de Mr. Le-Margne traducida al castellano y publicada en Madrid hacia 1740, pero constaba de seis tomos, y por otra parte el libro de Quiñones valía apenas un real.
Entre las obras de contenido más religioso o devocional, encontramos el del jesuita Eusebio Nieremberg, De la diferencia entre lo temporal y lo eterno. Crisol de desengaños, con la memoria de la eternidad... (Madrid, 1640), un "tratado de los sacramentos" que pudiera corresponder al Tratado de la administración de los Sacramentos del padre Luis de San Juan Evangelista (Madrid, 1652) y el "Flos Santorum" de Alonso de Villegas, uno de los libros más frecuentes en los inventarios $^{141}$. Esta obra, que constaba de seis libros (1568-1603), gozó de una enorme popularidad hasta el punto de hacerse más de cincuenta ediciones. Quiñones pudo tener una de las últimas en las que se agrupaban los distintos tomos, pues no se indica ninguno en particular. Poseía también dos tomos de los dos primeros meses del "Año Cristiano" 142 , una obra del jesuita Juan Croiset traducida al castellano por el padre José Francisco Isla. Tuvo gran aceptación en el siglo XVIII y el haberse publicado en Salamanca facilitaría su adquisición.

\footnotetext{
${ }^{141}$ F. MARTÍNEZ GIL, Muerte y sociedad en la España de los Austrias, Madrid, Siglo XXI, p. 74

142 Año cristiano, o ejercicios de piedad para todos los días del año, Salamanca, Eugenio García de Horio y San Miguel, 1753-1773.
} 